\title{
Production and downward flux of organic matter and calcite in a North Sea bloom of the coccolithophore Emiliania huxleyi
}

\author{
Paul van der Wal, Rob S. Kempers, Marcel J. W. Veldhuis \\ Netherlands Institute for Sea Research, PO Box 59, 1790 AB Den Burg, The Netherlands
}

\begin{abstract}
In July 1993, an extensive study was made of a large bloom of the coccolithophorid Emiliania huxleyi in the North Sea halfway between the Shetland lslands and Norway. Here we report on the hydrography, production and sedimentation of particulate organic carbon (POC) and calcite carbon (calcite-C) at 4 stations occupied for 24 h, 2 inside the bloom and 2 just outside. The coccolithophorid bloom was confined to North Sea waters, where a stable shallow mixed layer had been formed. Bloom development had entered the decaying phase, judged by the relatively low living cell number (maximally 1200 cells $\mathrm{cm}^{-3}$ ), the high number of loose coccoliths (up to 350000 coccoliths $\mathrm{cm}^{-3}$ ), and the fact that sedimentation of calcite-C exceeded production. In the top $15 \mathrm{~m}$ at the bloom stations, the mean daily production of coccoliths was 17 per cell. At the 2 stations outside the bloom, the dominant coccolithophore was a holococcolithophorid (up to 1400 cells $\mathrm{cm}^{-3}$ ), with insignificant amounts of calcite produced per cell. At these stations, nutrients were present in non-limiting concentrations and production of POC was twice as high as at the bloom stations. In the bloom, mixed layer nitrate levels were below $0.2 \mu \mathrm{M}$. Faecal pellets collected in the sediment traps contained large numbers of coccoliths of $E$. huxleyi. Although the numbers of grazers at the 2 stations outside the bloom were not lower than those in the bloom, the volume of faecal matter sedimenting at $50 \mathrm{~m}$ was about 70 times lower. It is hypothesized that faecal pellets outside the bloom were so light in weight that they did not sink very far before degradation, whereas the pellets produced in the E. huxleyi bloom in general were exported rapidly due to their heavy load of calcite. This implies that recycling of materials in the mixed layer of this bloom is relatively low due to high downward flux rate. The ratio at which $\mathrm{POC}$ and calcite-C were sedimenting amounted to 1.3 on average for the 2 bloom stations at $50 \mathrm{~m}$ water depth.
\end{abstract}

KEY WORDS: Emiliania huxleyi Coccoliths · Primary production - Calcification C Calcite dissolution Sedimentation - Faecal pellets - North Sea

\section{INTRODUCTION}

The prymnesiophyte algal group of the coccolithophores comprises one of the main groups of calcifying organisms in the photic zone of the oceanic environment. Intracellularly, they form calcitic particles, the coccoliths, which after completion are extruded and incorporated in the so-called coccosphere. The coccolithophorid skeletal remains are transported downward mainly in the form of faecal matter and aggregates (Honjo 1976, 1978, 1980, Honjo \& Roman 1978 ) and may contribute to up to $70 \%$ by weight to the total recent sediments covering the ocean floor

•E-mail: wal@nioz.nl above the calcite compensation depth (Mclntyre \& McIntyre 1971). It has been estimated that 0.8 gigatons of calcite carbon and 0.5 gigatons of organic carbon reach the ocean floor each year (Westbroek et al. 1993). This may show the importance of calcification as a regulatory mechanism in the global ocean carbon flux. Formation of $\mathrm{CaCO}_{3}$ causes a lowering of both the alkalinity and the dissolved inorganic carbon (DIC) and an increase in $\mathrm{CO}_{2}$ according to the following equation:

$$
\mathrm{Ca}^{2+}+2 \mathrm{HCO}_{3}^{-} \rightarrow \mathrm{CaCO}_{3}+\mathrm{CO}_{2}+\mathrm{H}_{2} \mathrm{O}
$$

Apparently, calcification is a sink for bicarbonate and a source of $\mathrm{CO}_{2}$ and, since this process mainly takes place in the sunlit part of the ocean, it tends to 
decrease the air to sea gradient of $\mathrm{CO}_{2}$. This may cause a diminished influx of $\mathrm{CO}_{2}$ into the sea or even an efflux of $\mathrm{CO}_{2}$ from the sea to the atmosphere. On the other hand, primary production, which only slightly affects alkalinity, provides an increase in the air to sea gradient of $\mathrm{CO}_{2}$. Coccolithophores also produce the gaseous compound dimethyl sulphide (DMS), which upon liberation into the atmosphere is oxidized to sulphate (cf. Charlson et al. 1987). Since this substance forms condensation nuclei for water vapour, cloud formation would be enhanced over areas with DMS production; the subsequent diminished solar irradiance may then act as a negative feedback mechanism for coccolithophorid growth and hence DMS production (Charlson et al. 1987).

In recent years much interest has been directed towards the study of the impact of coccolithophores on carbon and sulphur cycles in the global ocean and on world climate. To this purpose the Global Emiliania Modelling Initiative (GEM) was established, an international collaboration using the coccolithophore Emiliania huxleyi as a model organism (Westbroek et al. 1993). E. huxleyi is the dominant coccolithophorid species occurring world-wide in the ocean surface layer. It forms vast blooms of up to 1 million $\mathrm{km}^{2}$ especially at mid-latitudes in summer and early autumn, as was revealed by satellite imagery affirmed, in a number of cases, by in situ observations (Holligan et al. 1983. 1989, 1993a, b, Groom \& Holligan 1987, Ackleson et al. 1988, Brown \& Yoder 1994a, b). The satellite detection of blooms is accomplished by the enhanced light reflectance of the surface waters due to the occurrence of loose coccoliths in numbers of up to $400000 \mathrm{~cm}^{-3}$. The loose coccoliths may either be released by the living cell, by desintegration of whole coccospheres after cell lysis, or by zooplankton grazing of cells and subsequent desintegration of faecal matter. An extensive literature exists on the physiological and morphological characteristics of E. huxleyi, which is easy to cultivate under laboratory conditions (for references see Westbroek et al. 1993). Furthermore, the development of $E$. huxleyi blooms has been frequently monitored in mesocosms containing natural sea water to which varying amounts of nutrients were added (Bratbak et al. 1993, Egge 1993, Egge \& Heimdal 1994). Blooms occurring in the natural environment have also been thoroughly studied including two on the continental shelf of the Gulf of Maine (Balch et al. 1991, 1992), one at the shelf edge (Holligan et al. 1983) and one in the open ocean (Holligan et al. 1993a). However, many questions still remain as to the success of this species and its impact on the carbon and sulphur cycles.

In the North Sea area many blooms of Emiliania huxleyi develop each year in summer, as revealed by satellite imagery (Holligan et al. 1989, 1993b). Yet, only occasionally have in situ observations of blooms occurring here been reported. In July 1993 a cruise, named BLOOM 93, with the Dutch research vessel 'Pelagia' was undertaken to monitor a large number of physical, chemical and biological parameters in such E. huxleyi shelf sea blooms. By means of satellite images the ship was guided to a highly light-reflecting area situated halfway between the Shetland Islands and Norway (see Fig. 1). Upon arrival the water appeared to have a whitish, turquoise coloration characteristic for E. huxleyi blooms (Holligan et al. 1993a) and microscopic inspection of water samples revealed, indeed, the presence of this species. In this report we focus on experiments performed at 4 stations occupied for $24 \mathrm{~h}$, 2 of which were located inside the bloom and the other 2 outside, but in close proximity to the bloom. Here, we present (1) hydrographic data, (2) the calcite and particulate organic carbon (POC) production, and (3) the downward flux of particulate matter as measured with floating sediment traps. Our objectives were (1) to assess the growth conditions of an E. huxleyi bloom and (2) to quantify the impact of such a bloom on material fluxes, in particular that of carbon.

\section{MATERIAL AND METHODS}

Sampling stations. BLOOM 93 lasted from 28 June until 13 July 1993. Satellite images were recorded prior to and during the cruise by the Advanced Very High Resolution Radiometer (AVHRR) aboard the NOAA satellites. Image processing was done as in Groom \& Holligan (1987). A total of 34 stations were sampled. At 4 main stations, Stns 7, 12, 15 and 19, in situ experiments were performed lasting for $24 \mathrm{~h}$. In this study only the results obtained at these 4 stations are described. Stns 7 and 15 , respectively occupied on $1 / 2$ and $7 / 8$ July, were located within the bloom; Stns 12 and 19, respectively occupied on 4/5 and 10/11 July, were situated outside the bloom (see Fig. 1).

Hydrography and (bio)chemical analyses. Vertical profiles of salinity, temperature and the beam attenuation coefficient at $530 \mathrm{~nm}$ were recorded. The first 2 parameters were measured with a CTD manufactured by Sea-Bird Electronics type SBE9+. The beam attenuation coefficient was measured with a transmissometer manufactured by Dansk Havteknik (Denmark) and was corrected for the beam attenuation in pure seawater. The light levels of the solar irradiance at various water depths were measured at the sun's zenith with a spherical photosynthetic active radiation (PAR) $(400$ to $700 \mathrm{~nm}$ ) sensor.

At 04:00 h, water samples were collected using a rosette sampler with 10.5 I NOEX bottles (Technicap) from $2,5,10,15,25$ (27 at $\operatorname{Stn} 7), 40$ and $50 \mathrm{~m}$ for nutri- 
ents, dissolved inorganic carbon (DIC), POC, calcite, calcium-ions, chlorophyll a (chl a), phaeopigments, phytoplankton cells and loose coccoliths and for the assessment of rates of photosynthesis and calcification. Phosphate, nitrate, nitrite, ammonium and silica concentrations were measured in water samples filtered through Acrodisc filters with pore diameter $0.2 \mu \mathrm{m}$ (Gelman Sciences) by means of a Traacs 800 autoanalyzer. DIC was determined according to the coulometric method described in DOE (1991). POC was determined in material retained on $47 \mathrm{~mm}$, pre-combusted Whatman GF/F glass fibre filters after filtration of 3.5 to $5 \mathrm{l}$ of seawater sample. Filters were stored immediately at $-50^{\circ} \mathrm{C}$. In the laboratory, 12 circular punches, $4.2 \mathrm{~mm}$ in diameter, from each filter were placed in a small cup of tin foil and acidified with $\mathrm{H}_{2} \mathrm{SO}_{3}$ so as to volatilize the carbon present in the calcite. POC was analysed with a Carlo-Erba NA-1500 CHN analyser according to the Dumas combustion method. Calcite was measured in material retained on polycarbonate filters (Isopore) with pore diameter $0.8 \mu \mathrm{m}$ after filtration of 0.3 to $1.0 \mathrm{l}$ of seawater. While still in the fitration apparatus, filters were quickly rinsed twice with $5 \mathrm{ml}$ of a $5 \mathrm{mM} \mathrm{NH}_{4} \mathrm{HCO}_{3}$ solution $(\mathrm{pH}$ 8) to remove all seawater. Prior to filtration, filters and equipment were washed in $6 \mathrm{~N} \mathrm{HCl}$ and then carefully rinsed in a $5 \mathrm{mM}$ $\mathrm{NH}_{4} \mathrm{HCO}_{3}$ solution ( $\mathrm{pH} 8$ ). Filters were stored at room temperature. In the laboratory they were transferred to plastic tubes containing 5 to $10 \mathrm{ml} 0.1 \mathrm{~N} \mathrm{HCl}$ (supra pure) solution. After 12 to $18 \mathrm{~h}$ the Ca-ion concentration was measured in the solution with a flame atomic absorption spectrometer (Perkin Elmer 2380). Ca-ion concentrations in the seawater were determined by flame atomic absorption spectrometry after a 100- to 200-fold dilution of the samples with demineralized water. Chl a and phaeopigments were determined fluorometrically according to the method described by Holm-Hansen et al. (1965).

Phytoplankton analysis. To measure concentrations of coccospheres and loose coccoliths 0.1 to $1.0 \mathrm{l}$ samples were fixed in buffered formalin and carefully filtered through cellulose acetate filters with pore diameter $0.45 \mu \mathrm{m}$ (HAWP Millipore filters). Filters were stored at $-50^{\circ} \mathrm{C}$. In the laboratory the filters were dried and mounted on microsope slides with the resin Canada balsam (Serva), by which treatment they become transparent. Coccospheres and loose coccoliths were counted by viewing the preparations under a microscope using crossed polarizers. In combination with fluorescence microscopy the coccospheres containing chlorophyll, the living cells, could be distinguished from empty coccospheres, the dead cells.

Scanning electron microscopical studies have revealed that at least 4 coccolith morphotypes are present within the Emiliania huxleyi-complex (Young \&
Westbroek 1991). With antibodies raised against the polysaccharides present in the coccoliths the identification of 2 of these types, types A and B, could also be performed by light microscopy (Van Bleijswijk et al. 1991). Using the same antibodies we have made immunoassays according to the procedure described below. Water samples of $250 \mathrm{ml}$ to $1 \mathrm{l}$ were fixed in buffered formalin and then filtered through Sudan Black stained, $47 \mathrm{~mm}$ polycarbonate filters with $0.8 \mu \mathrm{m}$ pore size. The filters were stored at $-50^{\circ} \mathrm{C}$. In the laboratory filters were dried and cut into square pieces of about $1 \mathrm{~cm}^{2}$. These filter pieces were exposed to about $1 \mathrm{ml}$ of the various reactants and rinsing fluids used and transferred from one fluid to the next with a pair of tweezers. The composition and sequence of application of the fluids was as follows: Filtered seawater with $0.05 \%$ Tween (several minutes); filtered seawater containing $0.05 \%$ Tween, $1 \%$ newborn calf serum and the antibody $\left(1 \mathrm{~h}, 4^{\circ} \mathrm{C}\right.$ in the dark); filtered seawater with $0.05 \%$ Tween ( 3 times for several minutes); filtered seawater containing $0.05 \%$ Tween, $1 \%$ newborn calf serum and the fluorescent label swine anti-rabbit FITC $\left(30 \mathrm{~min}, 4^{\circ} \mathrm{C}\right.$ in the dark); filtered seawater with $0.05 \%$ Tween ( 2 times for several minutes); filtered seawater (several minutes). The filters were then dried and mounted on microscope slides with immersion oil and viewed in a fluorescence microscope.

By means of a flow-cytometer (EPICS CS), installed on board, algal groups present in $0.5 \mathrm{ml}$ untreated samples were counted and classified according to their size. The excitation wavelength used was $488 \mathrm{~nm}$ (Veldhuis \& Kraay 1990)

Some phytoplankton material sampled in the water column and also material collected in sediment traps (see below), that were mounted on either HAWP Millipore filters or polycarbonate filters prepared for light microscopical inspection, were also viewed in the scanning electron microscope. Small pieces of filter were mounted on aluminium stubs, coated with a thin layer of gold and examined in a Jeol 6400 at $25 \mathrm{kV}$.

Particulate carbon production and calcite dissolution. The production of $\mathrm{POC}$ and calcite was measured with the radioactive isotopes ${ }^{14} \mathrm{C}$ and ${ }^{45} \mathrm{Ca}$, respectively. Duplicate samples, contained in $60 \mathrm{ml}$ Nalgene bottles, were spiked with $222-259 \mathrm{kBq} \mathrm{NaH}^{14} \mathrm{CO}_{3}$ or $296-481 \mathrm{kBq}{ }^{45} \mathrm{CaCl}_{2}$ and incubated in the open sea at their depth of collection. These in situ incubations were terminated after $24 \mathrm{~h}$. Another set of samples, also contained in $60 \mathrm{ml}$ Nalgene bottles, were wrapped in black plastic foil after labeling and stored for $24 \mathrm{~h}$ at in situ temperature. Assuming that dark-uptake of label did not occur, these samples were used to correct uptake rates for adsorption of radionuclides to particulate matter and for ion-exchange effects. After incubation, ${ }^{14} \mathrm{C}$-labeled samples were carefully filtered 
through Whatmann GF/F filters at vacuum pressures below 0.2 bar, so as to avoid breakage of the cells. To remove excess label the $\mathrm{GF} / \mathrm{F}$ filters were acidified with fuming $\mathrm{HCl}$ for several minutes and dried at $60^{\circ} \mathrm{C}$ for several hours. After that, each filter was transferred to a scintillation vial to which, subsequently, was added $9 \mathrm{ml}$ of the scintillation fluid Instagel. After incubation, the ${ }^{45} \mathrm{Ca}$-labeled samples were suction-filtered through polycarbonate filters with $0.8 \mu \mathrm{m}$ pore size. While still in the filtration apparatus the filter was washed 3 times with $30 \mathrm{ml}$ filtered sea water in order to remove excess label. The filter was then transferred to a scintillation vial and subsequently soaked in $1 \mathrm{ml}$ $0.1 \mathrm{~N} \mathrm{HCl}$ to dissolve the calcite retained. Then $18 \mathrm{ml}$ Instagel was added. The type of filter used is of paramount importance in these experiments. Laboratory testing revealed that GF/F filters were superior to polycarbonate filters in causing the least damage to cells, while radioactive bicarbonate could still completely be removed from the GF/F filters by the acidifying and drying procedure described above. Excess radioactive $\mathrm{CaCl}_{2}$ can only be removed by thorough washing of the filters. In this process cells may easily break causing loss of the intracellular pool of labeled calcium other than coccoliths. Laboratory testing showed that excess ${ }^{45} \mathrm{Ca}$ could completely be removed from polycarbonate filters; the GF/F filters performed poorly in this respect. In order to determine the total amount of label added, $0.1 \mathrm{ml}$ sea water samples were taken from a selected number of spiked bottles. Samples were put in a scintillation vial and mixed with $9 \mathrm{ml}$ Instagel. The radioactivity was measured in a Wallac-LKB liquid scintillation analyzer, type 1909 Rackbeta. Quenching was corrected using the channels ratio method. The measured concentrations of DIC and Ca-ions were used to assess the specific activities of the respective labels.

One experiment was performed to determine calcite dissolution. Nine samples collected from $5 \mathrm{~m}$ depth at a station located within the Emiliania huxleyi bloom were spiked with $444 \mathrm{kBq}{ }^{45} \mathrm{CaCl}_{2}$ and were then incubated on deck. The incubator was kept at ambient sea water temperature. After $75 \mathrm{~h}$ the samples were wrapped in black plastic foil and placed back in the incubator. Radioactivity in the particulate fraction was measured after 4, 8, 24 and 48 h of dark incubation according to the procedure described above. One sample collected at the same site and depth and spiked with a similar amount of tracer was immediately incubated in the dark at ambient sea water temperature at the onset of the experiment. This sample was processed at the end of the experiment and was used to correct for adsorption and ion-exchange effects.

Sediment traps. The sediment traps used were $65 \mathrm{~cm}$ high funnels with a maximum width of $40 \mathrm{~cm}$ steeply tapering towards a removable sampling bottle. The cir-

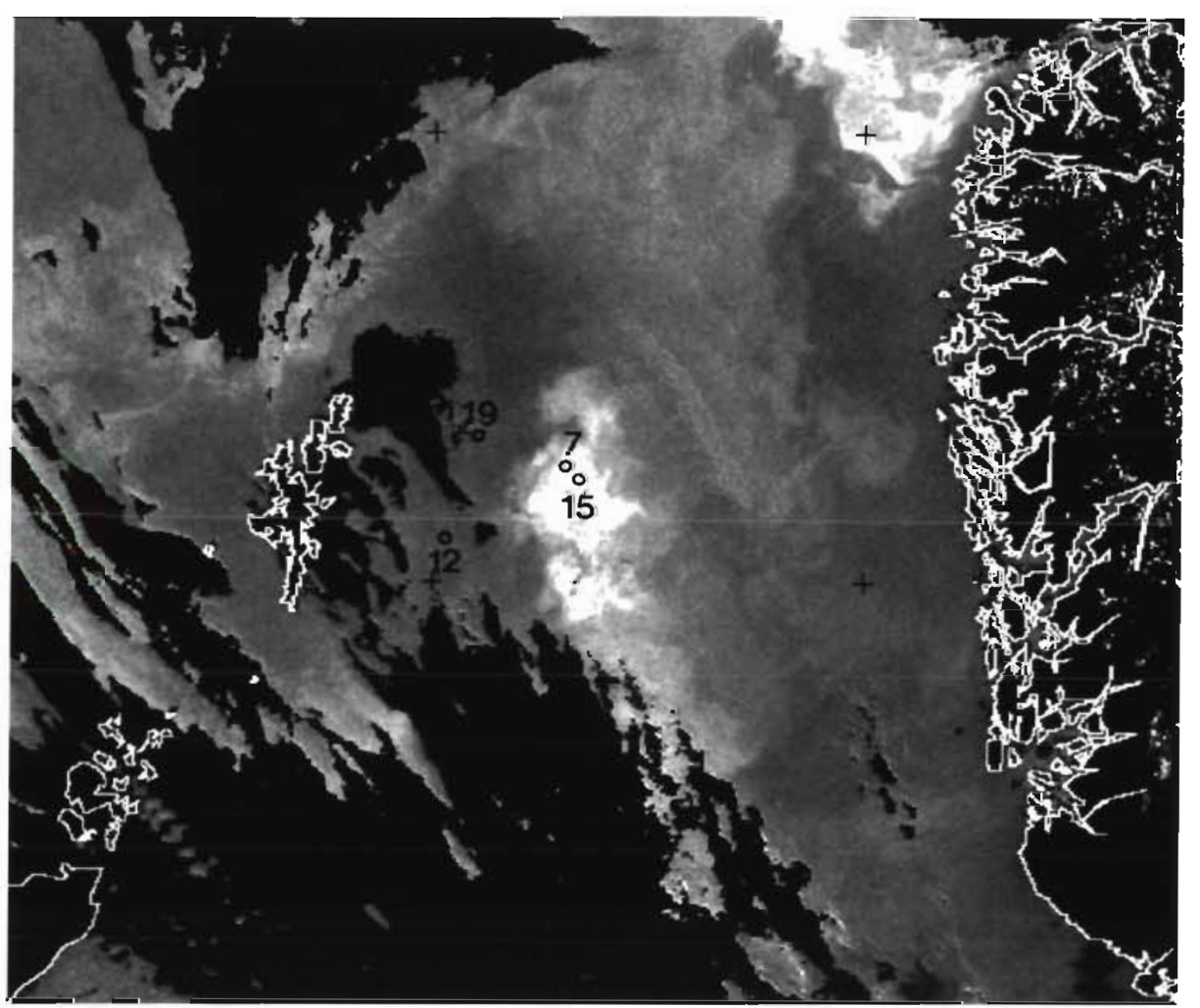

Fig. 1. AVHRR visible band image recorded on 27 June 1993 covering an area of the northern North Sea and adjacent Atlantic Ocean between $58^{\circ} \mathrm{N}$ (lower edge of mage) and $62^{\circ} 30^{\prime} \mathrm{N}$ and between $4^{\circ} \mathrm{W}$ and $7^{\circ} \mathrm{E}$. The high reflectance waters (lighter shades) off the east coast of Shetland demarcate the studied Emiliania huxleyi bloom. The positions of the 4 in situ stations are indicated. Land and clouds are masked in black 
cular catchment area had a diameter of $20 \mathrm{~cm}$ and contained a $1 \times 1 \times 5 \mathrm{~cm}$ deep grid. A valve above the bottle could be closed after recovery of the trap so as to avoid loss of sedimented material: without a valve the traps vigourously empty upon detachment of the bottle. These 'Kiel-type' traps (Zeitzschel et al. 1978) were deployed in duplicate during $24 \mathrm{~h}$ in the mixed layer at a depth of $10 \mathrm{~m}$ and below the mixed layer at $50 \mathrm{~m}$ depth. They were freely drifting and attached to a buoy equipped with a flash light and a radio beacon. To the bottle of one of the traps at each depth $50 \mathrm{ml}$ of a solution containing $18 \%$ formalin buffered with $20 \%$ hexamine was added to stop microbial and zooplankton activity. After collection, the trapped material was transferred to plastic containers, fixed in buffered formalin and stored at room temperature.

Caught zooplankton were identified and counted using a binocular microscope. Subsamples of the trapped material were filtered through cellulose acetate filters with pore diameter $0.45 \mu \mathrm{m}$ (HAWP Millipore filters), dried and mounted on microsope slides with Canada balsam. By this treatment they become suitable for microscopical investigation using transmitted light. The length and width of faecal pellets were measured and their volume calculated assuming that they were cylindrical or spherical in shape. POC and calcite were measured in material trapped by the poisoned and non-poisoned traps deployed at $50 \mathrm{~m}$ depth in the stations situated in the Emiliania huxleyi bloom (Stns 7 and 15). Subsamples were filtered over precombusted Whatman GF/F filters. From the material retained by the filters all zooplankters were removed, which include copepods, gastropods, pelecypods and Foraminifera. Each filter was then transferred to an ampoule to which subsequently $4 \mathrm{ml} \mathrm{3 \%}$ phosphoric acid was added. All $\mathrm{CO}_{2}$ escaping from the ampoule was measured in an infrared analyzer, 0524B Total Carbon System (Oceanography International Corporation, Cadée 1986). The result gives a measure of the total amount of detrital calcite-C retained on the filter. Next, in order to also measure the POC content, $200 \mathrm{mg}$ potassium persulphate was added to the same ampoule. After sealing and autoclaving, the ampoule was broken. All $\mathrm{CO}_{2}$ derived from the oxidation of organic matter was measured in the same infrared analyzer. Filters over which filtered seawater $(0.2 \mu \mathrm{m})$ was filtered were used as blanks.

\section{RESULTS}

\section{Hydrographic data}

Fig. 1 is a NOAA satellite image of the northern North Sea and adjacent Atlantic Ocean recorded in the period that RV 'Pelagia' visited the area. The high reflectance of the waters off the east coast of Shetland is the result of bloom development of the coccolithophorid Emiliania huxleyi: the large numbers of loose coccoliths formed during this development cause a relatively high backscatter of the incoming radiation. The position of the four $24 \mathrm{~h}$ stations are indicated in the figure. Stns 7 and 15 were located inside the bloom and Stns 12 and 19 outside of it. The water depths at these stations ranged between 134 and $145 \mathrm{~m}$. The beam attenuation coefficient c530 (corrected for the attenuation in pure sea water) was highest in the top layer of the coccolithophore-rich waters being about 1.5 and $1.0 \mathrm{~m}^{-1}$ at Stns 7 and 15, respectively (Fig. 2A). Between 20 and $40 \mathrm{~m}$, the beam attenuation coefficients rapidly declined and minimal values of about $0.05 \mathrm{~m}^{-1}$ were reached at $60 \mathrm{~m}$ water depth. Since the transparency of the water in these 2 stations is predominantly determined by the presence of detached coccoliths, the profiles show that the bulk of these particles is located in the top $30 \mathrm{~m}$ of the water column (see also below). At the other 2 stations, beam attenuation coefficients were also maximal in the top layer of
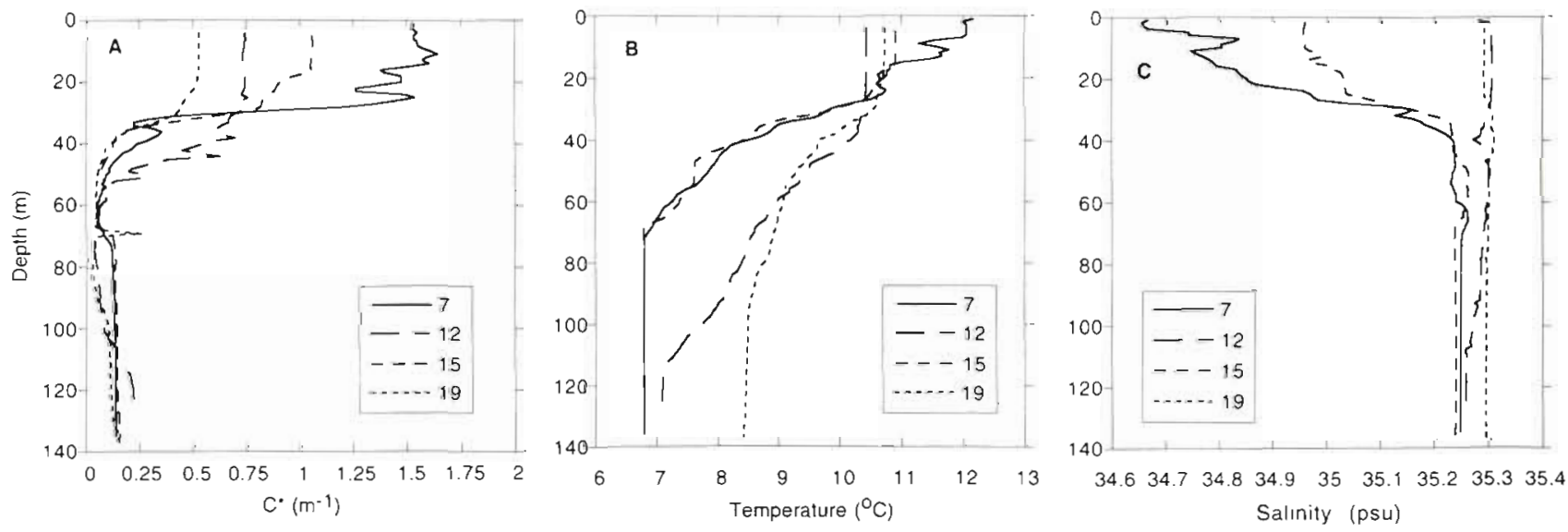

Fig. 2. (A) Light transmission profiles, recorded at $553 \mathrm{~nm},(\mathrm{~B})$ temperature profiles and (C) salinity profiles at Stns $7,12,15$ and 19 
the water column, reaching values of 0.7 and $0.5 \mathrm{~m}^{-1}$ at Stns 12 and 19, respectively, and declined below $20 \mathrm{~m}$ to minimal values of about $0.05 \mathrm{~m}^{-1}$ at $60 \mathrm{~m}$. The lower transparency in the top layer at Stn 12, as compared to the transparency at Stn 19, is caused by the fact that here both the content of detached coccoliths and chl $a$ were higher than at $\operatorname{Stn} 19$ (see below). The 1\% isolumen for the PAR was situated at 16,31 and $14 \mathrm{~m}$ water depth at Stns 7, 12 and 15, respectively. No PAR measurements were performed at Stn 19.

The temperature and salinity profiles recorded were very similar for Stns 7 and 15 (Fig. 2B, C): (1) the bottom of the thermocline was at about $70 \mathrm{~m}$, (2) the temperature of the bottom layer was $6.8^{\circ} \mathrm{C}$, (3) in the top $40 \mathrm{~m}$ of the water column a halocline had formed, and (4) below the halocline salinity remained rather constant at about 35.25 psu. The profiles at these stations differed in that at Stn 7 temperatures in the mixed layer were higher and salinities in the halocline were lower. The temperature and salinity profiles of Stns 12 and 19 showed considerable similarity in the first $60 \mathrm{~m}$ of the water column. Below that depth both temperature and salinity at Stn 12 started to deviate from those of $\operatorname{Stn} 19$, reaching values in the bottom layer that were very close to those measured at Stns 7 and 15. At Stn 19 the temperature of the water below the thermocline was about $8.4^{\circ} \mathrm{C}$ and the salinity values over the total water column showed a very narrow range of only 35.29 to 35.30 psu.

The low salinity layer at Stns 7 and 15 is established through the input of river water into the North Sea basin after the storm season. During winter North Sea waters are completely mixed at these sites (Otto et al. 1990). No fresh water input is apparent at Stns 12 and 19. The salinity in the upper water layer at Stn 12 is similar to that at Stn 19, whereas both salinity and temperature in the bottom layer at Stn 12 are similar to those at Stns 7 and 15. These observations clearly indicate that Stn 12 is positioned within the frontal system where Atlantic and North Sea waters meet. The waters at Stn 19 have an Atlantic signature.

The profiles for the phosphate (P) concentrations at Stns 7 and 15 show considerable similarity (Fig. 3A). Concentrations were lowest in the mixed layer, viz. about $0.1 \mu \mathrm{M}$, increased rapidly in the thermocline and remained more or less constant in the bottom layer at values of about $1.0 \mu \mathrm{M}$. The phosphate profile in the 'Atlantic' Stn 19 has a similar sigmoidal form, but the values only varied from $0.3 \mu \mathrm{M}$ in the mixed layer to $0.85 \mu \mathrm{M}$ in the bottom layer. At Stn 12 , the mixed layer concentrations of phosphate were intermediate between those of Stns 7 and 15 on the one hand and Stn 19 on the other. In the lower half of the thermocline concentrations were similar to those at Stn 19 and in the bottom layer a value was measured comparable to those found at Stns 7 and 15, which may again indicate that this layer has a North Sea signature.

The depth profiles for the nitrate concentrations are almost identical in shape to those of the phosphate concentrations (Fig. 3B). The mean values in the mixed layer at Stns 7 and 15 were 0.08 and $0.15 \mu \mathrm{M}$. respectively, and at Stns 12 and 19 were 1.48 and $3.93 \mu \mathrm{M}$, respectively. In the bottom layer nitrate concentrations were lowest at Stn 19. In the mixed layer ammonium concentrations were generally higher at Stns 7 and 15 as compared to those at Stns 12 and 19 (Fig. 3C). Maximum concentrations were attained in the thermocline layer and were especially prominent at Stns 7 and 15. This maximum is caused by the combined effect of remineralization of organic $\mathrm{N}$-compounds in the top $60 \mathrm{~m}$ of the water column and the incorporation of ammonium again into organic compounds by the autotrophic biota in the mixed layer.

The N/P ratios below the mixed layer at all 4 stations ranged between 13 and 15. In the mixed layer at Stns 12 and 19 these ratios were similar to those measured in the water column below. In the coccolithophore-rich mixed layer at Stns 7 and 15, the N/P ratios ranged
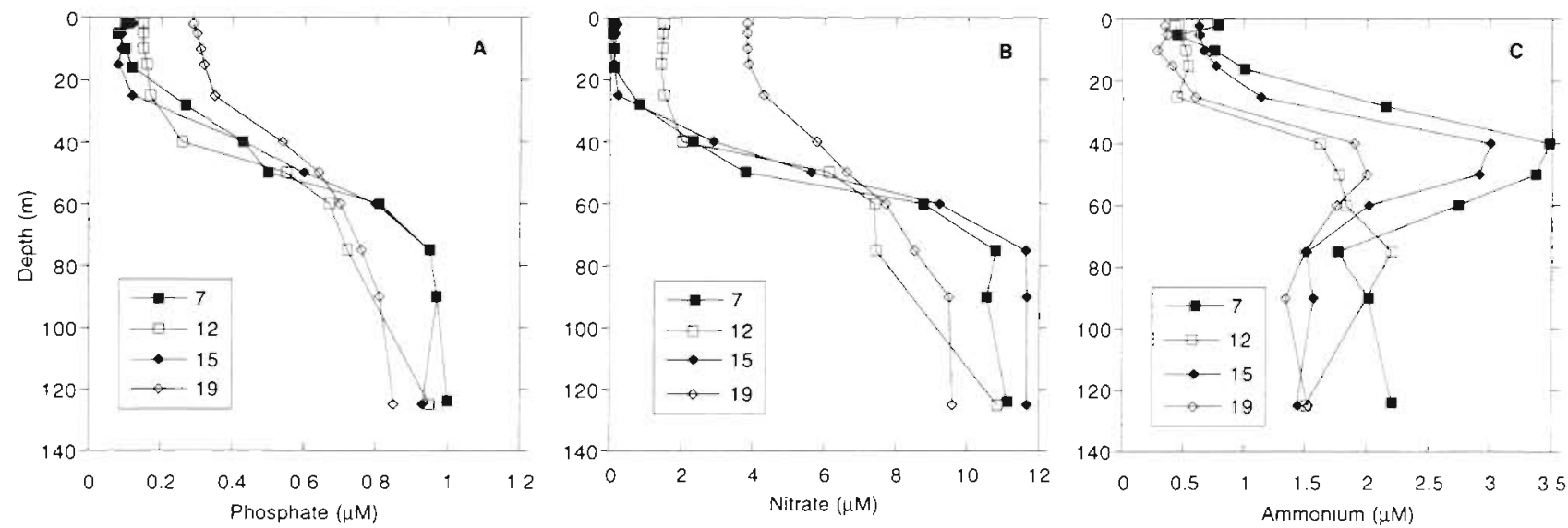

Fig. 3. (A) Phosphate, (B) nitrate and (C) ammonium concentrations at Stns 7, 12, 15 and 19 

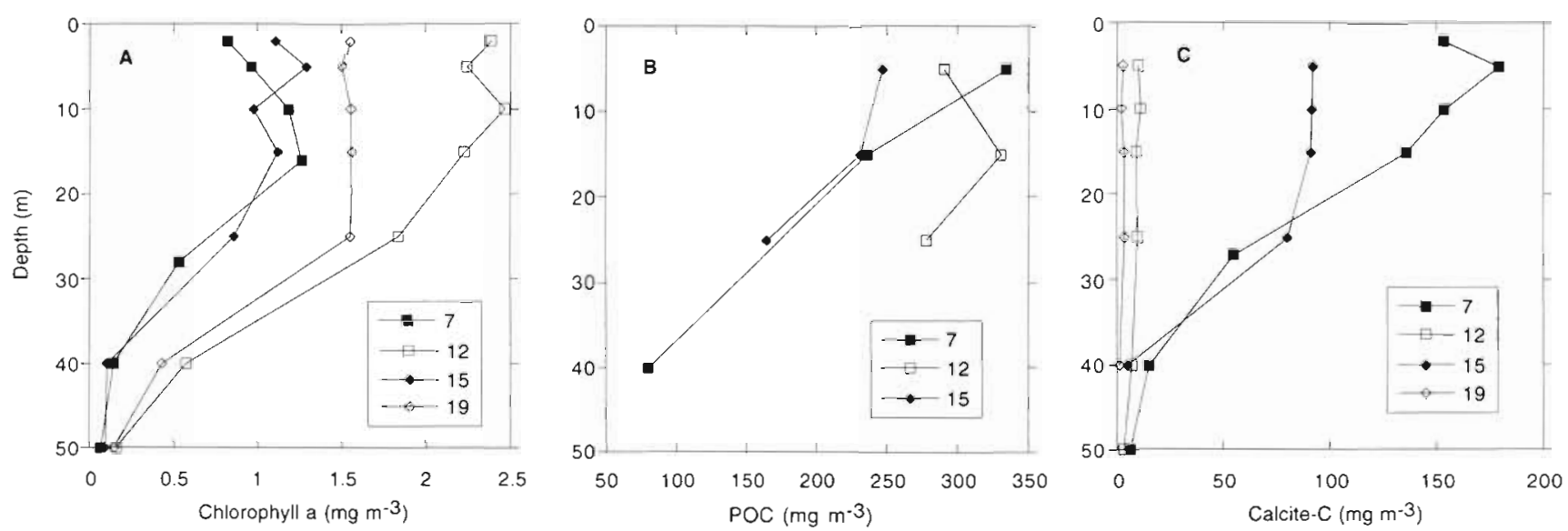

Fig. 4. (A) Chlorophyll a, (B) POC and (C) calcite-C concentrations at Stns 7, 12, 15 and 19

between 6 and 11. No data were collected on the concentrations of the dissolverd organic nitrogen and phosphorus compounds.

Si concentrations were only measured at Stns 7 and 12. In the mixed layer the average concentration amounted to $0.6 \mu \mathrm{M}$ in the 2 stations. In the thermocline layer concentrations rapidly increased to values of 5 to $7 \mu \mathrm{M}$ in the bottom layer (data not shown).

The chl a concentrations in the coccolithophore-rich mixed layer at Stns 7 and 15 were on average about twice as low as at $\operatorname{Stn} 12$ and about 1.5 times as low as at Str 19 (Fig. 4A). The mean chl a/phaeopigment ratios measured in the mixed layer at Stns 7 and 15 were 4.6 and 5.4, respectively. At Stns 12 and 19 these ratios were about 1.5 times higher amounting to 7.4 and 7.8, respectively. At Stns 7,12 and 15 only a limited number of samples were analysed for POC and particulate organic nitrogen (PON) content (Fig. 4B). In the stations located in the Emiliania huxleyi bloom a maximum POC content of $334 \mathrm{mg} \mathrm{POC} \mathrm{m}^{-3}$ was measured. Here, POC levels declined to less than $100 \mathrm{mg}$ POC $\mathrm{m}^{-3}$ at $40 \mathrm{~m}$ depth. Similar values were also measured at $\operatorname{Stn} 4$, which was also situated inside the $E$. huxleyi bloom. Outside the E. huxleyi bloom maximum POC levels were similar to those inside the bloom. Due to lack of data, a clear trend of POC concentrations with depth could not be assessed in the area outside the bloom. The POC/PON ratios in the mixed layer waters at Stns 7, 12 and 15 were $7.7,6.7$ and 6.8, respectively. In the top $15 \mathrm{~m}$ in the coccolithophorerich waters of Stns 7 and 15, the mean calcite-C concentration amounted to 155 and $92 \mathrm{mg} \mathrm{m}^{-3}$, respectively; below the mixed layer concentrations declined (Fig. 4C). At $50 \mathrm{~m}$ depth at $\operatorname{Stn} 7$, e.g. calcite-C content was only $6 \mathrm{mg} \mathrm{m}^{-3}$. At Stns 12 and 19 the mean calcite$C$ concentrations in the mixed layer were $10 \mathrm{mg} \mathrm{m}^{-3}$ and $3 \mathrm{mg} \mathrm{m}^{-3}$, respectively; at $50 \mathrm{~m}$ water depth calcite-C concentrations were about 3 times lower.

\section{Coccolithophores and other algal species}

The phytoplankton cells in the 4 stations were rather small with maximum diameters of about $6 \mu \mathrm{m}$. Cell numbers and biodiversity of the phytoplankton community were larger at Stns 12 and 19, the 2 Atlantic stations. The most conspicuous differences were the occurrence of large numbers of a holococcolithophorid species and a small pennate diatom species at Stns 12 and 19, which were absent at Stns 7 and 15. Also, flowcytometric analysis of sea water samples revealed the presence of a group of eukaryotes with a diameter of about 2 to $2.5 \mu \mathrm{m}$ in the former 2 stations, which were not detected in the latter 2. Cyanobacteria were an important constituent at all 4 stations. By flow-cytometry up to 35000 cells $\mathrm{cm}^{-3}$ were counted in the mixed layer at Stns 7 and 15, and about 50000 and 60000 cells $\mathrm{cm}^{-3}$ in the mixed layer at Stns 12 and 19, respectively. The immunofluorescence staining technique enabled us to distinguish between 2 morphotypes of Emiliania huxleyi by using fluorescence microscopy. It appeared that type A was the dominant morphotype. Type B was absent from Stn 19 and in the other 3 stations relatively low numbers of loose coccoliths of this type were found and only sporadically a whole coccosphere.

In the high reflectance waters, Emiliania huxleyi was the dominant coccolithophore. At Stn 7 living cell numbers showed a sharp maximum of about 1200 cells $\mathrm{cm}^{-3}$ at $10 \mathrm{~m}$ depth (Fig. 5A). The number of empty coccospheres (cells without detectable traces of chlorophyll) were about equally abundant in the top $30 \mathrm{~m}$ of the water column in this station amounting to about 600 specimens $\mathrm{cm}^{-3}$ (Fig. 5B). Here, the number of living cells exceeded the number of empty coccospheres by a factor of 1.5 on average. In the other station located in high reflectance waters (Stn 15) the total number of cells (living and dead) were quite similar to that found at $\operatorname{Stn} 7$. However, only about $20 \%$ of these 

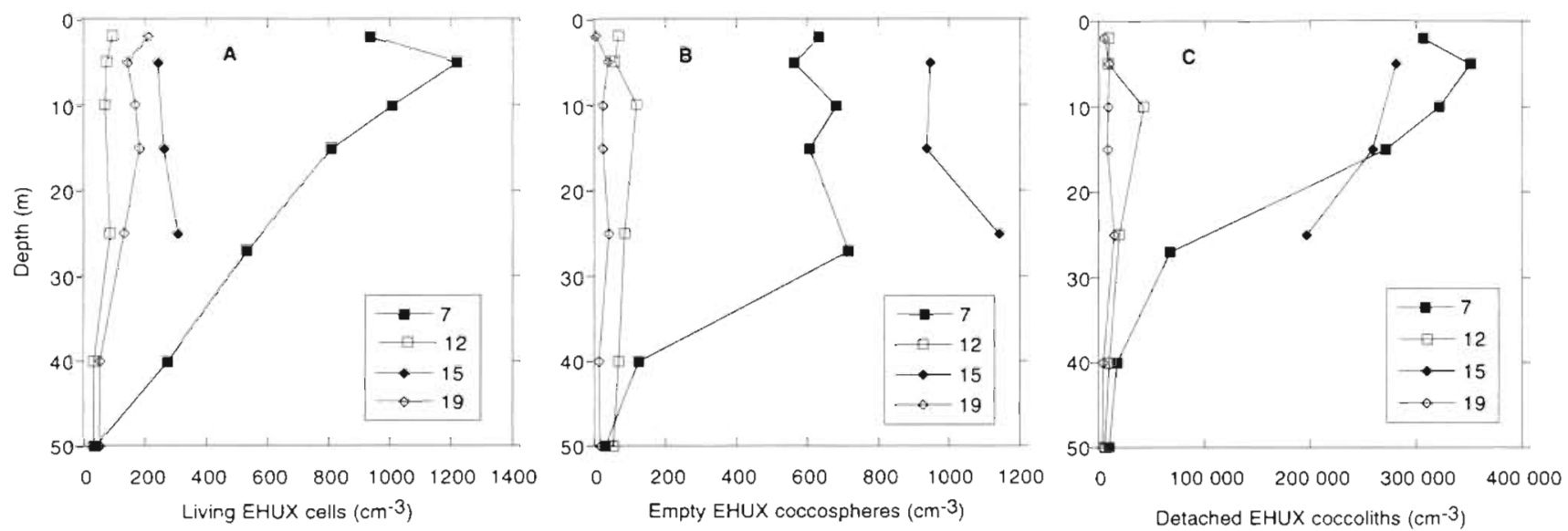

Fig. 5. Emiliania huxleyi (EHUX). Numbers of (A) living cells, (B) empty coccospheres and (C) loose coccoliths at Stns 7, 12,15 and 19

cells were alive (Fig. 5A, B). Within the E. huxleyi bloom 2 other heterococcolithophorid species were detected by using scanning electron microscopy. They only occurred in subordinate numbers and were identified as Syracosphaera pulchra and Algirosphaera sp.

At the 2 stations outside the Emiliania huxleyi bloom, the E. huxleyi cell numbers, i.e. living cells and empty coccospheres, amounted to about 200 cells $\mathrm{cm}^{-3}$ in the top $25 \mathrm{~m}$ of the water column in both stations (Fig. 5). At Stn 19 the viability of the E. huxleyi population was high with 3 to 50 times as many living cells as empty coccospheres. At Stn 12 living and dead E. huxleyi cells were present in about equal numbers. The dominant coccolithophore in these 2 stations was a holococcolithophore with a maximal count of about 1400 cells $\mathrm{cm}^{-3}$ at $5 \mathrm{~m}$ depth at Stn 19. Because of the low birefringence of their coccoliths they were not detected on the HAWP Millipore filters. However, due to the fact that their coccoliths showed a positive reaction with the antibody raised against the coccolith polysaccharide of E. huxleyi type A cells, this species could be distinguished and counted in the samples prepared for the immuno-assays. Subsequent scanning electron microscopy revealed that we dealt with an unknown species that can be classified as belonging to the genus Anthosphaera. The coccosphere is about $4 \mu \mathrm{m}$ in diameter and is composed of about 100 calyptroform ordinary holococcoliths and several fragarioform stomatal holococcoliths (cf. Kleijne 1991). A detailed description of this new, bloom-forming species will be published elsewhere.

Highest numbers of detached coccoliths were encountered in mixed layer waters of $\operatorname{Stn} 7$ with a maximum of over 350000 specimens $\mathrm{cm}^{-3}$; beneath the mixed layer in this station numbers rapidly declined to less than $10000 \mathrm{~cm}^{-3}$ at $50 \mathrm{~m}$ (Fig. 5C). At Stn 15, similar coccolith numbers were found in the mixed layer with a maximum of $281000 \mathrm{~cm}^{-3}$ at $5 \mathrm{~m}$. In the mixed layer waters of Stns 12 and 19 coccolith numbers amounted to about 20000 and $10000 \mathrm{~cm}^{-3}$ on average, respectively. At $5 \mathrm{~m}$ water depth, the loose coccolith/ coccosphere ratio was about 200 at Stns 7 and 15 and about 60 at Stns 12 and 19. There was a strong correlation between the concentration of detached coccoliths and the concentration of calcite- $\mathrm{C}$ as revealed by linear regression analysis of all data $\left(R^{2}=0.951, n=23\right)$. However, no proper estimate could be made of the amount of calcite-C per coccolith: at Stns 7 and 15, the attached coccoliths were incorporated in multilayered coccospheres and aggregates and no reliable counts could be obtained of the number of coccoliths present in themi at Stns 12 and 19 other coccolithophorid species contributed to a large extent to the measured calcite concentrations.

\section{Production of POC and calcite-C}

Photosynthetic rates were maximal in the upper $5 \mathrm{~m}$ of the water column amounting to about 80 and $60 \mathrm{mg}$ POC $\mathrm{m}^{-3} \mathrm{~d}^{-1}$ in the low reflectance waters of Stns 12 and 19 , respectively, and to about $40 \mathrm{mg} \mathrm{POC} \mathrm{m}^{-3} \mathrm{~d}^{-1}$ at the 2 stations located in the Emiliania huxleyi bloom (Fig. 6A). The rates gradually decreased with depth reaching values less than $2 \mathrm{mg} \mathrm{POC} \mathrm{\textrm {m } ^ { - 3 }} \mathrm{d}^{-1}$ below $25 \mathrm{~m}$ at the latter 2 stations and below $40 \mathrm{~m}$ at the other 2 stations. The total daily production of POC was about 2 times higher in the low attenuation waters as compared to that in the high attenuation waters with a maximum of $1329.5 \mathrm{mg}$ POC m $\mathrm{m}^{-2} \mathrm{~d}^{-1}$ at Stn 12 (Table 1). The differences in productivities are largely related to differences in both chl a content and transparency of the waters at the respective stations (see Figs. 2A \& 4A). The production of POC per unit chl a at the 4 in situ stations is illustrated in Fig $6 \mathrm{~B}$. In the top $5 \mathrm{~m}$ of the water column there was not much difference 

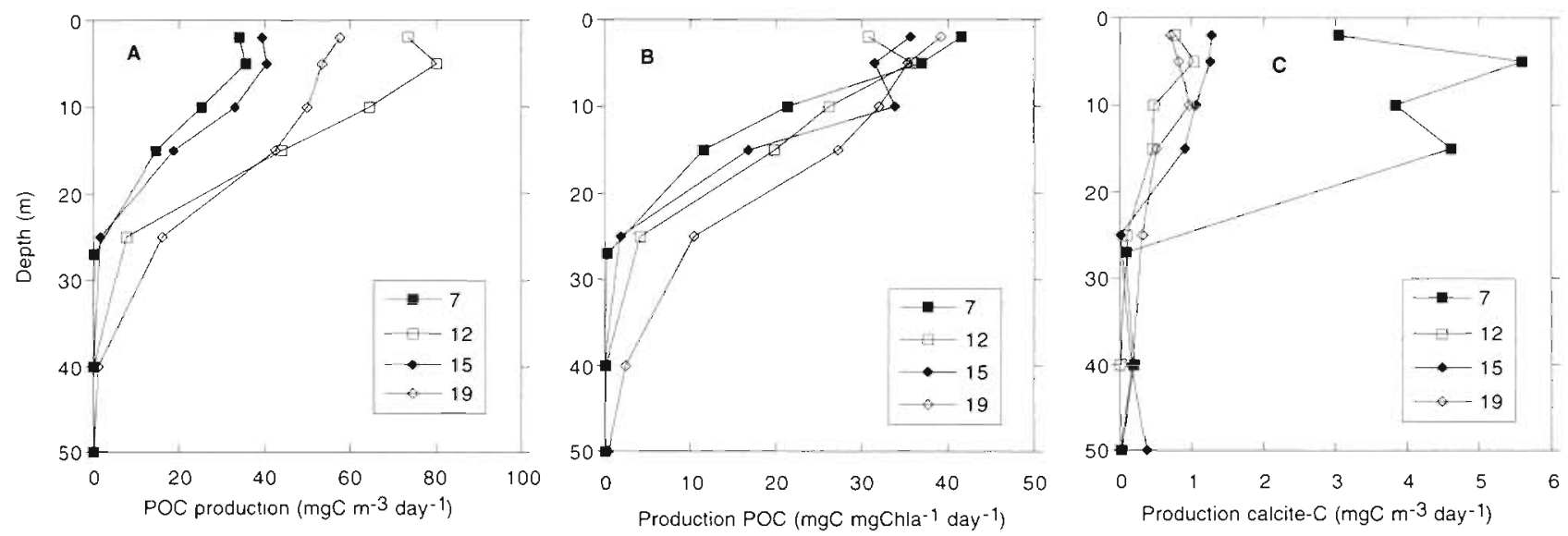

Fig. 6. (A) Production of POC, (B) production of POC per unit chlorophyll a and (C) production of calcite-C at Stns $7,12,15$ and 19

in chlorophyll performance among the stations with mean values ranging between 33 and $39 \mathrm{mg} P O C$

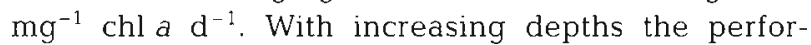
mance of chlorophyll declines at a rate that is largest at Stn 7 and smallest at Stn 19. This phenomenon is related to the transparency of the water in the mixed layer, which was minimal at $\operatorname{Stn} 7$ and maximal at Stn 19 (Fig. 2A).

The highest calcite- $C$ production was recorded at Stn 7 . Here, the daily production ranged between 3.0 and $5.6 \mathrm{mg}$ calcite- $\mathrm{C} \mathrm{m}^{-3}$ in the upper $15 \mathrm{~m}$ of the water column; below $27 \mathrm{~m}$ daily productions were less than $0.2 \mathrm{mg}$ calcite-C $\mathrm{m}^{-3}$ (Fig. 6C). At the other 3 stations, the highest productions were close to $1 \mathrm{mg}$ calcite-C $\mathrm{m}^{-3} \mathrm{~d}^{-1}$. The integrated daily production of calcite-C at Stn 7 was 4 to 7 times higher than at the other 3 stations (Table 1). At Stn 7, the total production of calcite-C amounted to $18 \%$ of that of the total production of $\mathrm{POC}_{i}$ in the other 3 stations the calcite-C production relative to POC production only ranged between 1 and $3 \%$ (Table 1 ).

Coccolithophores were the only calcifying organisms detected in the water samples in which the production measurements were performed. At Stns 7 and 15 this group consisted almost exclusively of the species Emiliania huxleyi, so that the daily production of calcite per

Table 1. Integrated production of POC and calcite-C and calcite-C/POC production ratios at Stns $7,12,15$ and 19

\begin{tabular}{|cccc|}
\hline Station & $\begin{array}{c}\text { POC } \\
\left(\mathrm{mg} \mathrm{m}^{-2} \mathrm{~d}^{-1}\right)\end{array}$ & $\begin{array}{c}\text { Calcite-C } \\
\left(\mathrm{mg} \mathrm{m}^{-2} \mathrm{~d}^{-1}\right)\end{array}$ & Calc-C/POC \\
\hline 7 (1 July) & 514.2 & 94.6 & 0.18 \\
15 (7 July) & 626.7 & 21.4 & 0.03 \\
12 (4 July) & 1329.5 & 13.8 & 0.01 \\
19 (10 July) & 1201.6 & 20.4 & 0.02 \\
\hline
\end{tabular}

E. huxleyi cell could be calculated. It appeared that the coccolith production in the top $15 \mathrm{~m}$ of the water column ranged between 12.5 and 21.9 coccoliths cell ${ }^{-1} \mathrm{~d}^{-1}$ and that somewhere between 15 and $27 \mathrm{~m}$ coccoliths production decreased to below 1.0 cell $^{-1} \mathrm{~d}^{-1}$ at $\operatorname{Stn} 7$ and to zero at Stn 15 (Table 2 ). The daily coccolith production per $E$. huxleyi cell integrated over the top 15 and $25 \mathrm{~m}$ of the water column was 15.9 and 15.6, respectively, at Stn 7 and 17.8 and 12.7 , respectively, at Stn 15 . We have also calculated the amount of calcite- $C$ produced per coccolithophorid cell in the 5 and $15 \mathrm{~m}$ samples at Stn 19. The production appeared to be about $0.50 \mathrm{pg}$ calcite- $C$ cell ${ }^{-1} \mathrm{~d}^{-1}$. This shows that the calcite$C$ production in the holococcolithophorid species, which dominated the coccolithophorid phytoplankton in these samples, was far less than that in E. huxleyi.

Table 2. Emiliania huxleyi. Numbers of living cells and daily production of calcite- $\mathrm{C}$ and coccoliths per cell at Stns 7 and 1.5

\begin{tabular}{|c|c|c|c|}
\hline $\begin{array}{l}\text { Depth } \\
\text { (m) }\end{array}$ & $\begin{array}{l}\text { Living EHUX } \\
\text { (cells } \mathrm{ml}^{-1} \text { ) }\end{array}$ & $\begin{array}{c}\text { Calcite-C } \\
\text { cell }{ }^{-1} d^{-1}(p g)\end{array}$ & $\begin{array}{l}\text { Coccoliths }{ }^{a} \\
\text { cell }^{-1} \mathrm{~d}^{-1}\end{array}$ \\
\hline \multicolumn{4}{|c|}{ Stn 7 (1 July) } \\
\hline 2 & 935 & 3.25 & 12.49 \\
\hline 5 & 1219 & 4.59 & 17.65 \\
\hline 10 & 1007 & 3.81 & 14.64 \\
\hline 15 & 809 & 5.70 & 21.91 \\
\hline 27 & 532 & 0.15 & 0.57 \\
\hline 40 & 271 & 0.71 & 2.72 \\
\hline 50 & 37 & 0.46 & 1.78 \\
\hline \multicolumn{4}{|c|}{ Stn 15 (7 July) } \\
\hline 5 & 240 & 5.19 & 19.96 \\
\hline 15 & 260 & 3.44 & 13.25 \\
\hline 25 & 305 & 0.00 & 0.00 \\
\hline \multicolumn{4}{|c|}{$\begin{array}{l}\text { a It is assumed that } 1 \text { coccolith of } E \text {. huxleyi contains } \\
0.26 \mathrm{pg} \text { calcite-C. This was calculated to be the average } \\
\text { amount of calcite-C per coccolith in an E. huxleyi bloom } \\
\text { in the Gulf of Maine, USA (Balch et al. 1992) }\end{array}$} \\
\hline
\end{tabular}




\section{Dissolution of calcite}

One experiment was also performed to measure the dissolution of $\mathrm{CaCO}_{3}$. For this purpose, water samples containing Emiliania huxleyi cells in concentrations of several hundreds per $\mathrm{cm}^{3}$ were spiked with ${ }^{45} \mathrm{CaCl}_{2}$ and incubated at ambient sea water temperature in an open deck incubator. After $75 \mathrm{~h}$ the water samples were wrapped in black plastic foil to stop coccolith formation. The concentration of radioactively labelled $\mathrm{CaCO}_{3}$ was measured after $4,8,24$ and $48 \mathrm{~h}$ of incubation in the dark (Table 3 ). Since the mean values did not show a decreasing trend in the course of time, the conclusion must be that at least during $48 \mathrm{~h}$ no dissolution of labelled $\mathrm{CaCO}_{3}$ took place in these samples.

Several phytoplankton samples were also viewed in the electron microscope to look for effects of calcite

Table 3 . Concentrations of radioactively labelled calcite after $4,8,24$ and $48 \mathrm{~h}$ of incubation in the dark. Spiked calcite was allowed to be formed during a light incubation period of $75 \mathrm{~h}$

\begin{tabular}{|cccc|}
\hline \multirow{2}{*}{$\begin{array}{l}\text { Duration of dark } \\
\text { incubation (h) }\end{array}$} & \multicolumn{3}{c}{ Labelled calcite $\left(\mathrm{mg} \mathrm{m}^{-3}\right)$} \\
Mean & SD & $\mathrm{n}$ \\
\hline 4 & 57.59 & 1.89 & 2 \\
8 & 51.93 & 0.23 & 2 \\
24 & 59.10 & 0.35 & 2 \\
48 & 54.82 & 2.53 & 3 \\
\hline
\end{tabular}

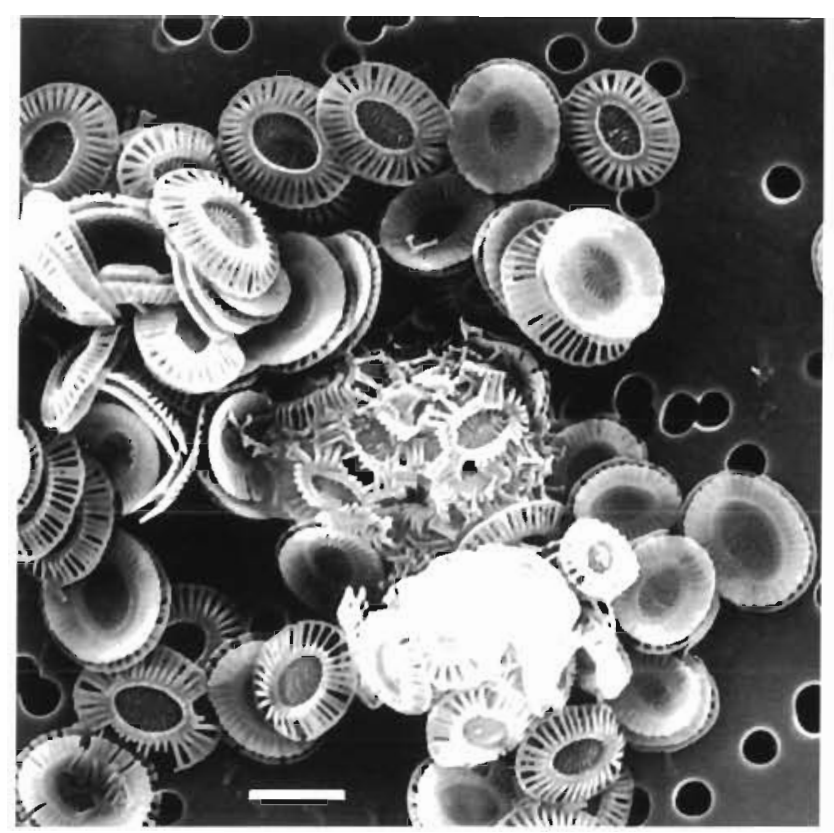

Fig. 7 Emiliania huxleyi. Scanning electron micrograph of deteriorated coccosphere (centre) surrounded by undamaged detached coccoliths and a whole coccosphere (bottom). Plankton sample collected at Stn 15 from $5 \mathrm{~m}$ depth. Scale bar $=2 \mu \mathrm{m}$ dissolution. Most coccospheres and free coccoliths sampled from within the Emiliania huxleyi bloom showed a fresh and solid appearance. However, also whole coccospheres were detected which were composed of coccoliths with incomplete and disjoined crystal elements (Fig. 7). It is possible that this aberrant appearance of cells is caused by dissolution of the coccoliths, implying that dissolution is a selective process (see 'Discussion').

\section{Sediment traps}

At each of the 4 in situ stations 4 sediment traps were deployed, viz. 2 at $10 \mathrm{~m}$ and 2 at $50 \mathrm{~m}$ depth. At each depth one of the traps was poisoned with formalin. It should be borne in mind that formalin kills all life forms preventing (1) the decomposition and consumption of sedimented material by heterotrophic organisms including microbes (e.g. Honjo \& Roman 1978, Azam et al. 1983, Gowing \& Silver 1983, Ducklow et al. 1985) and mesozooplankters (e.g. Lampitt et al. 1990, Noji et al. 1991) and (2) production, inside the trap, of faecal material, which otherwise would have been measured as sedimented matter (Lee et al. 1988). The most important mesozooplankton groups caught in the traps were copepods, gastropods and pelecypods. Their numbers are listed in Table 4. Echinoderm larvae, bryozoans and polychaetes were also encountered, but since they were often absent or occurred only in subordinate numbers, they are not listed here. In general, there is a large difference in copepod numbers between the poisoned and non-poisoned traps at both 10 and $50 \mathrm{~m}$ water depth with the highest numbers being always present in the poisoned trap. In our opinion this shows that during the deployment copepods actively swim into and out of the traps, but that many of those entering the poisoned traps get killed by the formalin and become trapped. Indeed, most of the copepod specimens had a fresh and undamaged appearance and hardly any debris of copepod remains was encountered.

The shallowest poisoned trap at each site always contained the largest number of copepods. This is probably due to the fact that the copepod population at $10 \mathrm{~m}$. depth is more abundant than that at $50 \mathrm{~m}$. Stn 19 ranked first in copepod abundance, followed by Stns 7 , 15 and 12 . The following 5 copepod genera were identified. Calanus, Metridia, Oithona, Pseudocalanus and Temora. Calanus was dominant in all the traps, except in those deployed at $10 \mathrm{~m}$ at Stns 12 and 19. At this depth at Stn 12 Oithona was most abundant, while the copepods found in the shallow trap at Stn 19 consisted for about $90 \%$ of Pseudocalanus, a genus that was rare or absent in all the other traps. Temora and Metridia 
Table 4. Numbers of copepods, gastropods and pelecypods and flux of faecal pellets in poisoned and non-poisoned sediment traps deployed at 10 and $50 \mathrm{~m}$ at Stns $7,12,15$ and 19

\begin{tabular}{|c|c|c|c|c|c|c|}
\hline Station & $\begin{array}{l}\text { Depth } \\
\text { (m) }\end{array}$ & Poisoned & Copepoda & Gastropoda & Pelecypoda & $\begin{array}{l}\text { Flux of faecal pellets } \\
\left(\mathrm{mm}^{3} \mathrm{~m}^{-2} \mathrm{~d}^{-1}\right)\end{array}$ \\
\hline 7 & 10 & Yes & 1280 & 572 & 344 & 258.7 \\
\hline 7 & 10 & No & 28 & 152 & 104 & 128.3 \\
\hline 7 & 50 & Yes & 16 & 0 & 64 & 1773.5 \\
\hline 7 & 50 & No & 8 & 32 & 72 & 4210.6 \\
\hline 15 & 10 & Yes & 464 & 40 & 60 & 292.7 \\
\hline 15 & 10 & No & 64 & 28 & 88 & 260.7 \\
\hline 15 & 50 & Yes & 204 & 4 & 4 & 727.6 \\
\hline 15 & 50 & No & 4 & 8 & 8 & 1043.5 \\
\hline 12 & 10 & Yes & 84 & 36 & 524 & 18.9 \\
\hline 12 & 10 & No & 32 & 60 & 424 & 51.1 \\
\hline 12 & 50 & Yes & 60 & 0 & 60 & 17.3 \\
\hline 12 & 50 & No & 4 & 7 & 8 & 56.5 \\
\hline 19 & 10 & Yes & 9696 & 896 & 160 & 11.0 \\
\hline 19 & 10 & No & 2752 & 1328 & 136 & 3.1 \\
\hline 19 & 50 & Yes & 1072 & 2056 & 3792 & 13.3 \\
\hline 19 & 50 & No & 28 & 196 & 1840 & 22.0 \\
\hline
\end{tabular}

were only found in the poisoned traps at Stn 19, the former in the shallow trap and the latter in the deep trap. In both cases their numbers were very low.

Gastropod and pelecypod numbers greatly differed among the non-poisoned and poisoned traps deployed at the same depth in each station, as was observed for the number of copepods. But contrary to what was found for the copepods, the highest numbers of gastropods and pelecypods were not always found in the poisoned traps. In fact the highest numbers in these traps were met in exactly half of the studied cases. We think that the large differences in gastropod and pelecypod numbers among paired traps largely arose through distortion of the hydrodynamical conditions induced by the trap system itself, resulting in a dissimilar performance of the traps (see 'Discussion'). This implies that the effect of the use of poison in assessing material fluxes cannot reliably be studied. For that reason, the average value of the flux rates measured separately in the paired non-poisoned and poisoned traps is considered to represent the best approximate for the real flux rates occurring at the site and depth of trap deployment.

Other important components found in the trap samples were round, oval or cylindrical pellets with a smooth and sharp outline, and aggregates having a jagged outline and irregular shape. The cylindrical material was most abundant and was very likely produced by copepods (cf. Martens 1978), which were the most prolific grazers as judged from the trap content. However, identification was problematic due to the fact that in most cases the cylinders occurred in frag- mented form. The origin of the round and oval pellets is unknown, but for convenience they will be classified together with the cylindrical pellets as faecal pellets. The irregular-shaped aggregates may have had a mixed origin or represented faecal pellets in a much desintegrated form. Faecal pellets and other aggregates were most abundant in the stations located in the Emiliania huxleyi bloom (Stns 7 and 15). At these stations, they almost exclusively consisted of the skeletal remains of $E$. huxleyi. Coccoliths always formed an integral part of faecal pellets and aggregates found in the other 2 stations also, but often to a much lesser degree. The oval and round pellets consisted of a dense packing of free coccoliths and whole coccospheres; these components always had a fresh and undamaged appearance (Fig. 8). In the cylindricalshaped pellets the coccoliths were mostly fragmented; whole coccospheres were not detected in them (Fig. 9).

In all traps the frequency distribution of the faecal pellet volumes had a positive skewness, as is shown in the percentile plot of Fig. 10. The median values ranged between 45000 and $404000 \mu^{3}$. The aspect ratios of the faecal pellets showed similar frequency distributions with the median values ranging between 1.3 and 5.8. In other words, the majority of the trapped faecal pellets were relatively small and short. The positive skewnesses of the frequency distributions of both the aspect ratio and the volume of the faecal pellets may indicate that they were subjected to desintegration during settling causing their mean to shift to lower values. The faecal pellet volumes had a normal distribution, when values were log-transformed. To test the 


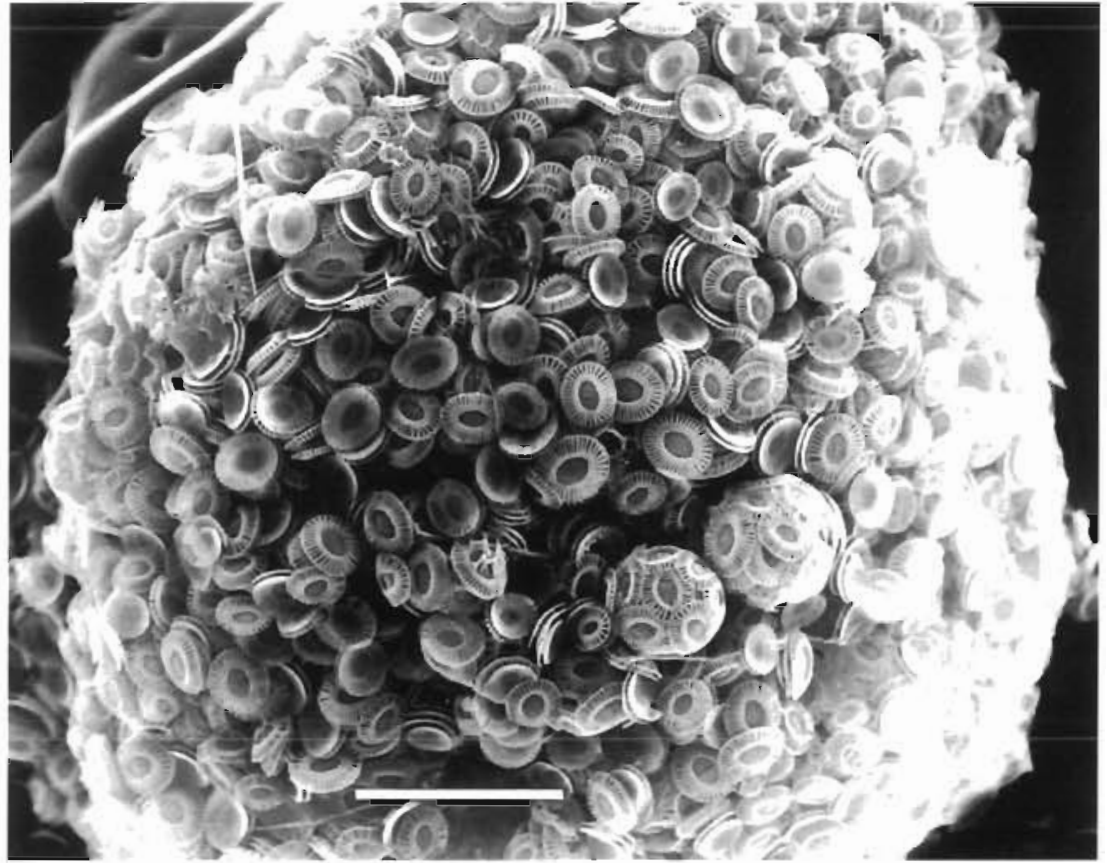

Fig. 8. Scanning electron micrograph of round pellet largely consisting of detached coccoliths and whole coccospheres of Emiliania huxleyi. Sample collected in sediment trap deployed at $10 \mathrm{~m}$ water depth at $\operatorname{Stn} 15$. Scale bar $=10 \mu \mathrm{m}$ effect of poisoning and of depth and position (within and outside bloom) of trap deployment on the mean volumes a 3-way analysis of variance was performed on the log-transformed data. It appeared that the mean faecal pellet volumes were (1) larger in the non-poisoned than in the poisoned traps $(p<0.01)$, (2) larger in the non-poisoned, deep traps than in the non-poisoned, shallow traps $(p<0.05)$ and (3) not significantly different in the bloom and non-bloom stations (compare also Fig. 10). The fact that the mean faecal pellet volume was larger in the non-poisoned traps is likely the result of the production of fresh faecal matter by grazers dwelling in the trap during deployment, an effect that was apparently larger in the traps at $50 \mathrm{~m}$ than at $10 \mathrm{~m}$.

The flux rates of faecal material caught in the traps are listed in Table 4 . These data also show, as for the pelecypod and gastropod numbers, that the performances of the paired traps differ markedly among one another (see 'Discussion'). The largest drain of faecal

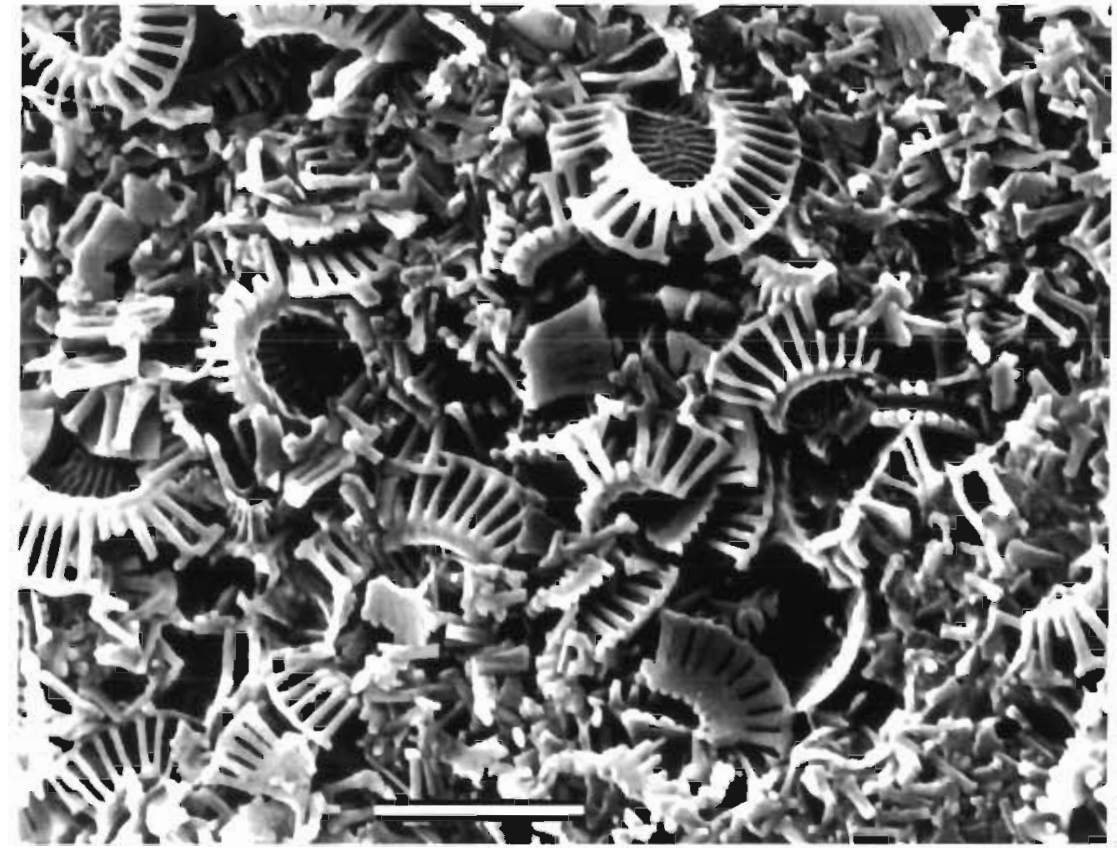

Fig. 9. Scanning electron micrograph showing detail of content of cylindncal pellet. Only skeletal remains of Emiliania huxleyt are visible. Sample collected in sediment trap deployed at $50 \mathrm{~m}$ water depth at $\operatorname{Stn} 7$. Scale bar $=2 \mu \mathrm{m}$ 


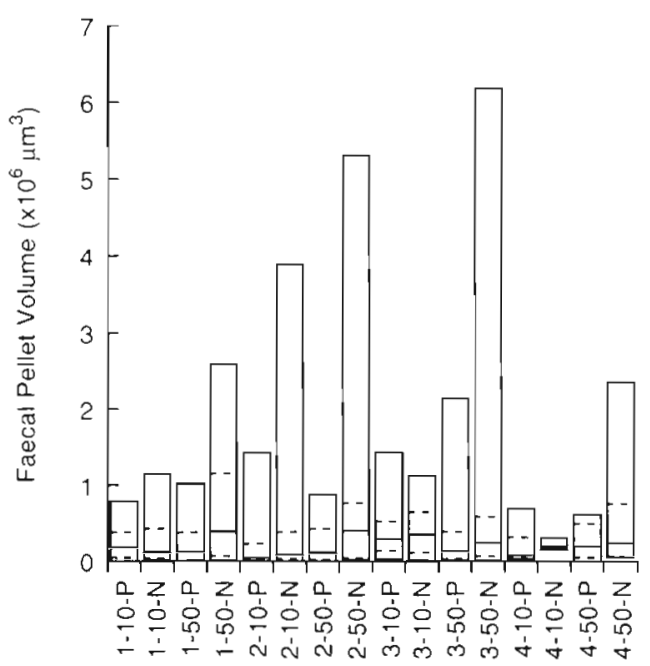

Fig. 10. Frequency distribution of the volumes of the faecal pellets caught in the 16 sediment traps deployed. The lower and upper ends of each box represent the $5 \%$ and $95 \%$ abundances, respectively. (-) median level; ( . . - -) $25 \%$ and $75 \%$ percentiles. The traps are coded as follows: the first number is the site (1: $\operatorname{Stn} 7,2: \operatorname{Stn} 12,3: \operatorname{Stn} 15,4: \operatorname{Stn} 19)$; the second number is depth in $\mathrm{m}$; $\mathrm{P}$ : poisoned; $\mathrm{N}$ : nonpoisoned

material occurred at Stns 7 and 15 located in the Emiliania huxleyi bloom. At $\operatorname{Stn} 7$, the mean flux at $10 \mathrm{~m}$ amounted to $193.5 \mathrm{~mm}^{3} \mathrm{~m}^{-2} \mathrm{~d}^{-1}$, which is $70 \%$ of the mean flux measured at $10 \mathrm{~m}$ at $\mathrm{Stn} 15$. The mean flux at $50 \mathrm{~m}$ at Stn 7 was $2992.1 \mathrm{~mm}^{3} \mathrm{~m}^{-2} \mathrm{~d}^{-1}$, which is $338 \%$ of the mean flux registered at Stn 15 at the corresponding depth. The mean fluxes calculated for both the poisoned and non-poisoned traps at Stns 7 and 15 were 3 to 15 times higher in the deep traps than in the shallow ones showing that the production was much larger in the upper $50 \mathrm{~m}$ than in the upper $10 \mathrm{~m}$ of the water column. The fluxes of faecal pellets at Stns 12 and 19 were insignificant compared to those of Stns 7 and 15. Also the fluxes measured at 10 and $50 \mathrm{~m}$ in each of these stations showed hardly or no difference. This is very remarkable given the fact that, especially at Stn 19, the standing stocks of copepods, gastropods and pelecypods were presumably very high relative to those found at Stns 7 and 15, as judged by the number of trapped specimens at these stations.
We have also measured the fluxes of POC and calcite-C at $50 \mathrm{~m}$ water depth at the stations situated in the Emiliania huxleyi bloom. For this purpose, the analysis was done on small subsamples from which all zooplankton specimens were carefully removed. Again, the large differences in content among the traps of the same depth are conspicuous (Table 5). The fluxes of calcite-C and POC at Stn 7 were 4 to 5 times as large on average as those at Stn 15 . The calcite$\mathrm{C} / \mathrm{POC}$ ratios in the 2 poisoned traps were close to 0.5 , whereas the ratios in the non-poisoned traps were larger than 1. Obviously, compared to the nonpoisoned traps, relatively more POC than calcite-C is caught in the poisoned traps.

The daily removal of calcite-C, as fraction of its standing stock, from the top layer by sedimentation amounted to $6.3 \%$ and $1.7 \%$ at Stns 7 and 15 , respectively (Table 6). The corresponding values for POC were about 2 times less. The amount of calcite- $C$ transported per day out of the upper $50 \mathrm{~m}$ was more than 2 times higher than the daily calcite-C production in this layer at both Stns 7 and 15. It shows that the Emiliania huxleyi population was in its declining phase. On the other hand, daily POC production was in excess of the daily POC flux indicating that $E$. huxleyi contributed only little to total primary production.

Table 5. Fluxes of calcite-C and POC in the poisoned and non-poisoned traps deployed at 50 meter at Stns 7 and 15

\begin{tabular}{|c|c|c|c|c|c|c|c|c|}
\hline \multirow[t]{2}{*}{ Stn } & \multirow[t]{2}{*}{ Poisoned } & \multicolumn{3}{|c|}{$\begin{array}{c}\text { Flux calcite-C } \\
\left(\mathrm{mg} \mathrm{m}^{-2} \mathrm{~d}^{-1}\right)\end{array}$} & \multicolumn{3}{|c|}{$\begin{array}{c}\text { Flux POC } \\
\left(\mathrm{mg} \mathrm{m}^{-2} \mathrm{~d}^{-1}\right)\end{array}$} & \multirow[t]{2}{*}{$\begin{array}{l}\text { Flux calc-C/ } \\
\text { Flux POC }\end{array}$} \\
\hline & & Mean & $S D$ & $\mathrm{n}$ & Mean & SD & $\mathrm{n}$ & \\
\hline 7 & Yes & 153.60 & 3.61 & 4 & 241.88 & 15.78 & 3 & 0.64 \\
\hline 7 & No & 356.40 & 18.69 & 4 & 325.24 & 22.87 & 4 & 1.10 \\
\hline 15 & Yes & 58.52 & 3.61 & 4 & 113.91 & 17.67 & 3 & 0.51 \\
\hline 15 & No & 38.34 & 0.51 & 4 & 28.52 & 2.66 & 4 & 1.34 \\
\hline
\end{tabular}

Table 6. Summary of standing stocks, productions and fluxes of calcite-C and POC in the upper $50 \mathrm{~m}$ of the water column at Stns 7 and 15

\begin{tabular}{|c|c|c|c|c|c|}
\hline & $\begin{array}{l}\text { St. stock } \\
\left(\mathrm{mg} \mathrm{m}^{-2}\right)\end{array}$ & $\begin{array}{l}\text { Production } \\
\left(\mathrm{mg} \mathrm{m}^{-2} \mathrm{~d}^{-1}\right)\end{array}$ & $\begin{array}{c}\text { Flux }^{\mathrm{d}} \\
\left(\mathrm{mg} \mathrm{m}^{-2} \mathrm{a}^{-1}\right)\end{array}$ & $\begin{array}{c}\text { Flux/St. stock } \\
(\%)\end{array}$ & $\begin{array}{c}\text { Flux/Prod. } \\
(\%)\end{array}$ \\
\hline \multicolumn{6}{|c|}{ Calcite-C } \\
\hline $\operatorname{Stn} 7$ & 4047.9 & 94.6 & 255.0 & 6.3 & 269.6 \\
\hline $\operatorname{Stn} 15$ & 2921.0 & 21.4 & 48.4 & 1.7 & 226.3 \\
\hline \multicolumn{6}{|l|}{ POC } \\
\hline $\operatorname{Stn} 7$ & 9063.8 & 514.2 & 283.6 & 3.1 & 55.1 \\
\hline $\operatorname{Stn} 15$ & 7731.3 & 626.7 & 71.2 & 0.9 & 11.4 \\
\hline
\end{tabular}




\section{DISCUSSION}

\section{Development of the Shetland bloom}

The large continental shelf Emiliania huxleyi bloom investigated here was confined to water derived from the North Sea, as was demonstrated in vertical profiles of salinity, temperature and nutrients. Almost every year dense blooms of $E$. huxleyi develop in the Norwegian fjords (Berge 1962) starting with populations living at rather low salinities (Kristiansen et al. 1994). In 1993 satellite images of the North Sea area revealed that the first signs of blooms were apparent by the beginning of June in the fjord systems in southwest Norway. Shortly after that extensive blooms were recorded in the adjacent Norwegian current; by the end of June the bloom east of Shetland, which we have studied, was registered in the visible band images (Van der Wal et al. unpubl.). This westward displacement of the blooming phase of E. huxleyi is possibly related to the spread of low saline runoff waters, which may have facilitated the forming of a stable shallow mixed layer, a condition that appears to be a prerequisite for the prolific growth of E. huxleyi (Berge 1962, Balch et al. 1991, Holligan et al. 1993a, b, this study).

We have shown that in the Emiliania huxleyi bloom the flux of calcite-C exceeds the production of calcite$C$ by a factor of more than 2 . This is a clear indication that at the studied sites the bloom was already past its culmination. This is also apparent from the relatively high photosynthesis/calcification ratios of 5.4 and 29.3 measured in the productive layer at Stns 7 and 15 , respectively: in culminating $E$. huxleyi blooms induced to grow in mesocosms, this ratio was below 2 (Van der Wal et al. 1994). In general, high concentrations of loose coccoliths on the one hand and low cell numbers on the other indicate that such blooms have entered into their decaying phase.

The results of the sediment traps demonstrated that the drain of matter from the productive layer inside the bloom was much larger than outside the bloom. We assume that this is caused by the higher recycling rate of faecal matter outside the bloom (see below). This implies that in blooms of Emiliania huxleyi nutrients may rapidly be exhausted, whereas outside such blooms substantial remineralization of nutrients in the productive layer may account for a prolonged sustenance of large phytoplankton populations. Indeed, nitrate concentrations in the $E$. huxleyi bloom were very low as compared to those in the waters adjacent to the bloom. Furthermore, there was hardly any or no peak of ammonium below the mixed layer at the 2 stations outside the bloom contrary to what was found at the other 2 stations. This may show that, outside the bloom, regeneration of $\mathrm{N}$-compounds was confined to the mixed layer to a large extent. The rapid drawdown of nutrients from the mixed layer undoubtedly has a strong impact on the phytoplankton composition and, consequently, on the development of the E. huxleyi bloom. It is thought that the increasingly lower nutrient levels result in the gradual disappearance of species, until finally those species survive which have the highest competitive strength at low nutrient levels. Due to its low nutrient requirements (Eppley et al. 1969) E. huxleyi may endure these conditions for a very long time, so that a rather pure bloom of this species may be formed. However, the positive feedback of the success of this species on the further removal of nutrients finally makes conditions for this species also unbearable.

The phytoplankton present in the decaying Emiliania huxleyi bloom studied here appeared to be nitrogen limited, as was shown in short bioassays in which the ratio of the intracellular glutamine/glutamate ratio before and after a pulse of ammonium was used as an index for nitrogen limitation (Flynn 1990, Willem Stolte pers.comm.). Possibly, nitrogen limitation may have been the prime cause for the bloom's decline. In the summer of 1989 an E. huxleyi bloom was studied in the Gulf of Maine, USA, which resembled the Shetland bloom in many respects including coccosphere and loose coccolith number and concentrations of nutrients and chlorophyll (Baich et al. 1992). Nutrient enrichment experiments showed that there both calcification and primary production were nitrate limited. Likewise, mesocosm experiments have shown that nutrient depletion may cause the decline of E. huxleyi blooms (Bratbak et al. 1993, Egge \& Heimdal 1994). Another cause for a bloom to decay is by the infection of $E$. huxleyi cells by virus particles, as was also demonstrated in mesocosm experiments (Bratbak et al. 1993). In an E. huxleyi bloom occurring south of Iceland in June 1991, nutrient levels did not attain limiting levels and viruses were not observed to have infected the cells (Holligan et al. 1993a). Possibly, light level was the limiting factor here: the beam attenuation coefficients at $532 \mathrm{~nm}$ in the high reflectance waters of the Iceland bloom were about 2 times higher than in the high reflectance waters in the Shetland bloom (Holligan et al. 1993a, this study).

\section{Production}

The calcite-C production per cell in Emiliania huxleyi blooms has been monitored in two $4 \mathrm{~m}$ deep mesocosms in spring 1992 in Bergen, Norway (Van der Wal et al. 1994). It appeared that this production was similar in all stages of bloom development amounting to average values of 3.82 and $4.22 \mathrm{pg}$ calcite-C cell ${ }^{-1} \mathrm{~d}^{-1}$ 
These values are similar to those measured in the top $15 \mathrm{~m}$ at Stns 7 and 15 (Table 2) and also similar to the maximum rate measured in an E. huxleyi bloom occurring in the Samnangerford, Norway (Kristiansen et al. 1994). In an E. huxleyi bloom occurring south of Iceland in the summer of 1991 Fernandez et al. (1993) measured a cell-specific calcification rate that was about twice as low.

In mesocosm studies of Emiliania huxleyi blooms it was shown that the loose coccolith/coccosphere ratios were below 30 in the initial stages and rapidly increased to between 50 and 200 a few days after the bloom had reached its peak (Van Bleijswijk et al. 1994a). By this criterium also the Shetland bloom is shown to be in a late developmental stage. It was suggested that the Iceland bloom had also entered into its final stage by Holligan et al. (1993a). Yet, the loose coccolith/coccosphere ratio did not exceed 40 (Fernandez et al. 1993). Coccoliths in the coccosphere are embedded in a polysaccharide-containing organic substance (see e.g. Van der Wal et al. 1983), which may act as a glue to hold the coccoliths together. It is possible that in the Iceland bloom the stickiness of coccoliths was enhanced preventing (1) the easy release of coccoliths from calcifying cells and (2) the ready desintegration of empty coccospheres. Also, aggregate formation of loose coccoliths may have been much enhanced in the Iceland area due to microturbulence conditions that were different from those prevalent in the shelf sea bloom.

We have shown that the calcification rates per Emiliania huxleyi cell at Stns 7 and 15 were very high in the upper $15 \mathrm{~m}$ of the water column and that a steep decrease occurred in coccolith production between 15 and $25 \mathrm{~m}$. Taking into consideration that the $1 \%$ light level for PAR was situated at about $15 \mathrm{~m}$, these results may show that coccolith formation is saturated at very low irradiances. On the other hand, photosynthesis was saturated at much higher light levels, as judged from the gradual decrease of organic carbon production per unit chl a with depth. It should be stated here that the values of the calcification rates presented have already been corrected for the coccolith formation in the dark. Therefore, the alternative explanation can be excluded that the E. huxleyi cells in the mixed layer would have drawn from an intracellular energy reservoir large enough to sustain coccolith formation, while the cells below this layer would have exhausted their intracellular energy supplies, as a result of a prolonged deprivation of light. It has been shown in both longterm (Van Bleijswijk et al. 1994b) and short-term experiments (Balch et al. 1992, Fernandez et al. 1993) that calcite production in E. huxleyi may, indeed, become saturated at very low irradiances. However, various short-term experiments have also been con- ducted yielding the opposite result of calcite productions being saturated at very high irradiances (Paasche 1964, Balch et al. 1992, Fernandez et al. 1993, Nimer \& Merrett 1993). This discrepancy may be inherent to short-term experiments in which cells are not allowed to adapt to changing conditions. The low light saturation level for coccolith formation in the Shetland bloom is in agreement with the model presented by Balch et al. (1992).

At Stn 7 highest calcification rates were measured. Here the integrated calcite-C production amounted to $18 \%$ of the integrated POC production. This value is comparable to that calculated for the in situ station with maximal calcification in the Iceland bloom (Fernandez et al. 1993). In Emiliania huxleyi blooms induced to grow in mesocosms the calcite-C/POC production ratios rose to over 0.5 when the blooms were close to their culmination (Van der Wal et al. 1994). These values were measured at $2 \mathrm{~m}$ water depth. At the corresponding depth at Stn 7 the calcite-C/POC production ratio was about 5 times lower, which indicates that even at this station the Shetland bloom had developed into its post-culmination stages.

In this study we have shown that in radio-tracer experiments coccoliths did not dissolve within up to $5 \mathrm{~d}$ after their formation (Table 3 ). On board experiments were also performed to determine dissolution of $\mathrm{CaCO}_{3}$ in the Emiliania huxleyi bloom by measuring the standing stock of $\mathrm{CaCO}_{3}$ in sea water samples that had been incubated in the dark for 0,24 and $28 \mathrm{~h}$. It appeared that the $\mathrm{CaCO}_{3}$ standing stocks might diminish by up to $25 \%$ within $24 \mathrm{~h}$ of dark incubation (Buitenhuis et al. unpubl.). The conclusion that can be drawn from these results is that dissolution of $\mathrm{CaCO}_{3}$ only occurs in old coccoliths and that freshly formed coccoliths, i.e. coccoliths that are at least younger than $5 \mathrm{~d}$ (the maximal duration of the experiment), are not affected. In mesocosm blooms of E. huxleyi it was demonstrated that dissolution of $\mathrm{CaCO}_{3}$ started only after the culmination of the bloom with a rate of about $5 \%$ of the $\mathrm{CaCO}_{3}$ standing stock per day, a phenomenon that was assessed by comparing the $\mathrm{CaCO}_{3}$ standing stock and the cumulative amount of $\mathrm{CaCO}_{3}$ produced (Van der Wal et al. 1994). This may show that dissolution is related to the bloom's decay in such a manner that dissolution only affects the coccoliths in decaying cells. This view is consistent with the finding that freshly formed coccoliths are not liable to dissolution, because these coccoliths are most likely still incorporated in the coccospheres of viable, calcifying cells. At macro-environmental level no clues are apparent as to the causes of calcite dissolution. We think, therefore, that each decaying E. huxleyi cell is a micro-environment in which $\mathrm{CO}_{2}$ concentrations are enhanced through either the inorganic decomposition 
of organic material, or the heterotrophic activity of microbial organisms causing the coccolith-calcite to dissolve. Such a selective dissolution of coccolith calcite is in agreement with our scanning electron microscope (SEM) observations of the co-occurrence of fresh-looking and deteriorated coccospheres (Fig. 7).

\section{Sedimentation}

We have shown that often large differences were observed in the numbers of caught pelecypods and gastropods, and in the amount of caught faecal material, POC and calcite- $\mathrm{C}$ among the traps that formed a paired system. In our opinion these differences largely arose through distortion of the hydrodynamical conditions induced by this system itself, as will be explained in the following. The double trap system probably attained an orientation parallel to the current in the water, so that one of the traps had an upstream position with respect to the other one. In that situation the upstream trap might have produced so much turbulence around the funnel opening of the downstream trap that the downward flux of particulate matter into this trap was strongly influenced (e.g. Honjo 1978). We think that this problem would not have occurred, if a shield or rudder (e.g. Gundersen 1991) was attached to the double trap system. In that case the system might have oriented itself transverse to the current, so that the traps would have met similar hydrodynamical conditions. Due to the dissimilar performance of the traps, the effect of the use of poison in assessing material flux rates could not reliably be studied.

We have found that the fluxes of faecal pellets at Stns 12 and 19 were insignificant compared to those at Stns 7 and 15, despite the fact that, especially at Stn 19, the standing stocks of copepods, gastropods and pelecypods were presumably very high relative to those found at Stns 7 and 15, as judged by the number of trapped specimens at these stations (Table 4). We offer the following explanation to this phenomenon. Inside the Emiliania huxleyi bloom mesozooplankters consume large amounts of coccoliths. These particles have a high specific weight and, hence, their ingestion would lead to a higher sedimentation rate of the faecal pellets produced. In contrast, in waters outside the $E$. huxleyi bloom the residence time of faecal material in the top 10 and $50 \mathrm{~m}$ of the water column is relatively high, because of the lower sedimentation rate. Biological activity is an important mechanism in the recycling of faecal material. There is growing evidence that the consumption and desintegration is largely accomplished by microbial organisms (Honjo \& Roman 1978 , Turner 1979, Gowing \& Silver 1983, Jacobson \& Azam 1984, Ducklow et al. 1985) and meso- and macrozoo- plankton (Paffenhöfer \& Strickland 1970, Smetacek 1980, Lampitt et al. 1990, Noji 1991, Noji et al. 1991). Lower sedimentation rates would then lead to a higher degree of consumption and desintegration of faecal pellets by bacteria and coprophagous organisms. Moreover, in the process, faecal pellets become smaller and less compact resulting in even lower sedimentation rates (Noji et al. 1991). In short, the downward transport of faecal material in the E. huxleyi bloom was greatly enhanced due to the ballasting effect of the coccoliths.

Similar to our findings, Voss (1991) observed that changes in the diet of copepods, in response to changes in the phytoplankton composition, could lead to increased sedimentation rates of particulate matter from the productive surface layer. Rapid recycling in combination with low sinking rates of faecal matter in the euphotic zone have also been inferred from various other field studies, whether conducted in fresh water lakes, shelf seas or the open ocean (Ferrante \& Parker 1977. Smetacek 1980, Krause 1981, Alldredge et al. 1987, Bathmann et al. 1987, Cadée et al. 1992, Gonzalez et al. 1993). The importance of coccoliths as a ballasting material in accellerated downward transport has also been revealed in several other field studies. Honjo $(1978,1980)$ found that all faecal pellets definitely originating from the productive layer ('green' faecal pellets) that were trapped at meso- and bathypelagic depths at various sites in the Atlantic and Pacific Oceans were loaded with coccolithophorid calcite remains. Also, long-term sediment trap studies have revealed that coccolithophorid blooms were associated with increased material fluxes. In the Panama Basin in June through July 1980 a bloom of the coccolithophorid Umbilicosphaera sibogae caused a material flux that was up to 2 orders of magnitude larger than the usual fluxes measured in that year (Honjo 1982). Knappertsbusch \& Brummer (in press) have found that faecal matter stuffed with the coccolithophorid remains of Syracosphaera pulchra were associated with enhanced material fluxes in the open ocean. From the differences in arrival times of the spikes at the various depths of trap deployment the average sinking velocity of the particles was estimated to be about $150 \mathrm{~m} \mathrm{~d}^{-1}$.

Sinking rates of particles are dependent on their specific weight, shape and size. With respect to faecal pellets it has been demonstrated that (1) the density of faecal pellets is positively related to sinking rate (Bienfang 1980, Voss 1991, Cadée et al, 1992); (2) round and oval pellets have relatively higher settling velocities than cylindrical ones due to lower form resistance to sinking (Cadée et al. 1992); (3) large pellets settle more quickly than smaller ones (Cadée 1986, Cadée et al. 1992). Alldredge et al. (1987) and Cadée et al. (1992) have demonstrated that faecal pellets, that did not sink 
out from the mixed layer, settled at several tens to hundreds of meters per day in laboratory experiments. Other laboratory experiments have also invariably shown high sedimentation rates of faecal material (for references see Cadée et al. 1992, Harris 1994). Obviously, these experiments do not mimick the conditions in the natural environment. In nature settling velocities may be reduced by (1) microbial gas development in faecal material, as suggested by Krause (1981); (2) fragmentation (coprorhexy) and 'loosening' (coprochaly) of pellets due to meso- and macrozooplankton activity (Lampitt et al. 1990, Noji 1991, Noji et al. 1991); or (3) turbulence and density discontinuity layers not present in the laboratory settling tubes, as suggested by Cadée et al. (1992).

The calcite-C flux measured in the Emiliania huxleyi bloom ranged between 38 and $356 \mathrm{mg} \mathrm{C} \mathrm{m}^{-2} \mathrm{~d}^{-1}$ with an average of $152 \mathrm{mg} \mathrm{C} \mathrm{m} \mathrm{m}^{-2} \mathrm{~d}^{-1}$; the flux of POC ranged between 29 and $325 \mathrm{mg} \mathrm{C} \mathrm{m}^{-2} \mathrm{~d}^{-1}$ with an average of $177 \mathrm{mg} \mathrm{C} \mathrm{m}^{-2} \mathrm{~d}^{-1}$. Fluxes of particulate carbon were also determined in the above-mentioned Umbilicosphaera sibogae bloom occurring in the open ocean. Here, the calcite-C and organic carbon fluxes in the shallowest trap $\left(890 \mathrm{~m}\right.$ ) were 191 and $25 \mathrm{mg} \mathrm{C} \mathrm{m}^{-2}$ $\mathrm{d}^{-1}$, respectively, averaged over a period of 2 mo (Honjo 1982). Thus, calcite-C fluxes in the 2 blooms were similar. The lower POC fluxes measured in the relatively deep trap in the open ocean station is probably the result of the rapid remineralization of POC in the upper few hundred meters of the water column. Carbon fluxes in a non-coccolithophorid bloom, the colonial microflagellate Corymbellus aureus, have been measured on Fladen Ground, about 100 miles south of the area investigated here, using the same type of free-floating traps (Cadée 1985, 1986). The highest flux recorded was $43.7 \mathrm{mg} \mathrm{C} \mathrm{m}^{-2} \mathrm{~d}^{-1}$ occurring when the bloom was declining. This value is low compared to the POC flux measured in the E. huxleyi bloom. The accelerated transport of POC in coccolithophorid blooms is probably accomplished by the packaging of organic matter in fast sinking coccolithladen particles (see also Honjo 1978). An additional mechanism to explain the enhanced material fluxes may be related to the consumption of large amounts of coccoliths by mesozooplankters. Since these particles are not nutritious, all ingested coccoliths end up in faecal pellets, which at unchanged ingestion rates would lead to higher rates of defaecation. Harris (1994) has calculated the flux of calcite-C mediated by 2 common copepod species in a shelf-break bloom and an oceanic bloom of E. huxleyi based on actual field abundances and laboratory experiments on the egestion rates of calcite-C by these copepods fed exclusively with $E$. huxleyi cells. The flux in the shelf-break bloom was in the lower range of values measured in the Shetland bloom; the flux in the oceanic bloom was insignificant due to the low abundance of copepods.

We have found that at Stns 7 and 15 the calcite$\mathrm{C} / \mathrm{POC}$ ratios in the poisoned traps were much lower than in the non-poisoned traps (Table 5). Obviously, compared to the non-poisoned traps, relatively more POC than calcite-C is caught in the poisoned traps. It is possible that the amount of POC sedimented in the non-poisoned trap is reduced by biological induced remineralization of POC during deployment (heterotrophy of microbes and mesozooplankters). Alternatively, the amount of POC found in the poisoned trap may give rise to an overestimation of the flux as a result of the presence of the preservative formalin: Formalin may have been diffused into the funnel of the trap where it would have caused the aggregation of organic matter, which subsequently was rapidly deposited in the sampling bottle of the trap. Artifacts may also have been introduced due to precipitation of the hexamine buffer or the formalin (Gundersen 1991). Thus, both the POC values of the poisoned and nonpoisoned traps may not be very reliable. Nevertheless, the similarity of the calcite-C/POC flux ratios among the 2 stations strongly indicates that $\mathrm{POC}$ and calcite$\mathrm{C}$ are transported with the same vehicle.

Probably as a result of the accellerated downward transport of materials out of the mixed layer nutrients were almost exhausted (this study) in this layer and surface DIC levels were about $10 \mu \mathrm{mol} \mathrm{kg-1}$ lower compared to the levels found immediately outside the bloom (Buitenhuis et al. unpubl.). The ratio at which $P O C$ and calcite-C are exported from the mixed layer effect the relative abundances of the components of the carbonate system. For instance, preliminary results of a numerical model study of Emiliania huxleyi blooms showed that the $\mathrm{fCO}_{2}$ in the final stages of the bloom is lowered compared to the fugacity in the prebloom phase due to the fact that together with calcite$\mathrm{C}$ also POC is exported from the mixed layer. If only calcite-C had been exported, $\mathrm{fCO}_{2}$ would have risen above the pre-bloom levels in the final stage.

We have found that in the cylindrical-shaped pellets coccoliths were mostly fragmented (Fig. 9). This may have been due to (1) the feeding habits of the grazing organism causing mechanical wear of the coccoliths and/or (2) the combination of mechanical wear and weakening of the calcite through dissolution occuring in the gut of the grazer. According to Harris (1994) calcite may dissolve in the digestive tract of copepods. Contrary to the cylindrical pellets the oval and round pellets found in the traps were all composed of undamaged coccoliths and coccospheres (Fig. 8). They may represent faeces of a zooplankter different from those producing the cylindrical-shaped pellets. On the other hand, they may not be faeces at all, but aggregates 
similar to the macroaggregates of whole Emiliania huxleyi cells described by Cadée (1985). It is unknown how these macroaggregates are formed. Knowledge of the conditions regulating their formation is important, since these particles may contribute considerably to the downward flux of POC and calcite.

Acknowledgements. We thank officers and crew of RV 'Pelagia' for excellent support during BLOOM 93. We are grateful to Karel Bakker, Jan Hegeman, Jan Derksen, Anna Noordeloos, Willem Stolte, André Buijs, Gert Jan Gast, Bert Aggenbach and Rikus Kloosterhuis for technical assistance, to Steve Groom for processing the satellite image and to Jaap van der Meer for performing statistical tests. We thank Gerhard Cadée, Peter Westbroek and Erik Buitenhuis for their valuable comments. Thanks are also due to Saskia Kars for preparing the electron micrographs and to Annelies Kleijne for her advice on the taxonomy of coccolithophores. Part of this research was subsidized by the Netherlands Organization for Scientific Research (NWO) and the National Research Program on Global Air Pollution and Climate Change (NOP). This is EHUX contribution No. 43.

\section{LITERATURE CITED}

Ackleson S, Balch WM. Holligan PM (1988) White waters of the Gulf of Maine. Oceanography 1:18-22

Alldredge AL, Gotschalk CC, MacIntyre S (1987) Evidence for sustained residence of macrocrustacean fecal pellets in surface waters off Southern California. Deep Sea Res 34: $1641-1652$

Azam F, Fenchel T, Field JG, Meyer-Reil LA, Thingstad F (1983) The ecological role of water-column microbes in the sea. Mar Ecol Prog Ser 10:257-263

Balch WM, Holligan PM, Kilpatrick KA (1992) Calcification, photosynthesis and growth of the bloom-forming coccolithophore Emiliania huxleyi. Cont Shelf Res 12: $1353-1374$

Balch WM, Holligan PM, Ackleson SG, Voss KJ (1991) Biological and optical properties of mesoscale coccolithophore blooms in the Gulf of Maine. Limnol Oceanogr 36(4):629-643

Bathmann UV, Noji TT, Voss M, Peinert R (1987) Copepod fecal pellets: abundance, sedimentation and content at a permanent station in the Norwegian Sea in May/June 1986. Mar Ecol Prog Ser 38:45-51

Berge $G$ (1962) Discoloration of the sea due to Coccolithus huxleyi 'bloom' Sarsia 6:27-40

Bienfang PK (1980) Herbivore diet affects faecal pellet settling. Can J Fish Aquat Sci 37(9):1352-1357

Bratbak G, Egge JK, Heldal M (1993) Viral mortality of the marine alga Emiliania huxleyi (Haptophyceae) and termination of algal blooms. Mar Ecol Prog Ser 93:39-48

Brown CW, Yoder JA (1994a) Coccolithophorid blooms in the global ocean. J geophys Res 99(C4):7467-7482

Brown CW, Yoder JA (1994b) Distribution pattern of coccolithophorid blooms in the western North Atlantic Ocean. Cont Shelf Res 14(2/3):175-19?

Cadée GC (1985) Macroaggregates of Emiliania huxleyi in sediment traps. Mar Ecol Prog Ser 24:193-196

Cadée GC (1986) Organic carbon in the water column and its sedimentation, Fladen Ground (North Sea), May 1983. Neth J Sea Res 20(4):347-358
Cadée GC, Gonzalez H, Schnack-Schiel SB (1992) Krill diet affects string settling. Polar Biol 12:75-80

Charlson RJ, Lovelock JE, Andreae MO, Warren SG (1987) Oceanic phytoplankton, atmospheric sulphur, cloud albedo and climate. Nature 326:655-661

DOE (1991) Handbook of methods for the analysis of the various parameters of the carbon dioxide system in sea water version 1.0. Dickson AG, Goyet C (eds). ORNL/CDIAC-74 Department of the Environment, UK

Ducklow HW, Hill SM, Gardner WD (1985) Bacterial growth and the decomposition of particulate organic carbon collected in sediment traps. Cont Shelf Res 4(4):445-464

Egge JK (1993) Nutrient control of phytoplankton growth effects of macronutrient composition (N, P, Si) on species succession. PhD thesis, University of Bergen

Egge JK, Heimdal BR (1994) Blooms of phytoplankton including Emiliania huxleyi (Haptophyta). Effects of nutrient supply in different N:P ratios. Sarsia 79(4):333-348

Eppley RW, Rogers JN, McCarthy JJ (1969) Half-saturation constants for uptake of nitrate and ammonium by marine phytoplankton. Limnol Oceanogr 14:912-920

Fernandez E, Boyd P, Holligan PM, Harbour DS (1993) Production of organic and inorganic carbon within a largescale coccolithophore bloom in the northeast Atlantic Ocean. Mar Ecol Prog Ser 97:271-285

Ferrante JG, Parker JI (1977) Transport of diatom frustules by copepod fecal pellets to the sediments of Lake Michigan Limnol Oceanogr 22:92-98

Flynn KJ (1990) The determination of nitrogen status in microalgae. Mar Ecol Prog Ser 61:297-307

Gonzalez HE, Gonzalez SR, Brummer GJA (1993) Short-term sedimentation pattern of zooplankton, faeces and microplankton at a permanent station in the Bjornafjorden (Norway) during April-May 1992. Mar Ecol Prog Ser 105 $31-45$

Gowing MM, Silver MW (1983) Origins and microenvironments of bacteria mediating fecal pellet decomposition in the sea. Mar Biol 73(1):7-16

Groom SB, Holligan PM (1987) Remote sensing of coccolithophore blooms. Adv Space Res 7(2):73-78

Gundersen K (1991) Sampling precision and preservation of sediment trap material. In: Wassmann P, Heiskanen AS, Lindahl $O$ (eds) Sediment trap studies in the nordic countries. Symposium Proceedings. Nurmi Print $O$, Nurmijärvi, p 157-175

Harris RP (1994) Zooplankton grazing on the coccolithophore Emiliania huxleyi and its role in inorganic carbon flux. Mar Biol 119:431-439

Holm-Hansen O, Lorenzen CJ, Holmes RW, Strickland JDH (1965) Fluorometric determination of chlorophyll. J Cons perm int Explor Mer 30(1):3-15

Honjo S (1976) Coccoliths: production, transportation and sedimentation. Mar Micropaleontol 1:65-79

Honjo S (1978) Sedimentation of materials in the Sargasso Sea at a 5,367 m deep station. J mar Res 36(3):469-493

Honjo S (1980) Material fluxes and modes of sedimentation in the mesopelagic and bathypelagic zones. J mar Res 38(1): $53-97$

Honjo S (1982) Seasonality and interaction of biogenic and lithogenic particulate flux at the Panama Basin. Science 218:883-884

Honjo S, Roman MR (1978) Marine copepod fecal pellets: production, preservation and sedimentation. $\mathrm{J}$ mar Res 36(1): $45-57$

Holligan PM, Aarup T, Groom SB (1989) The North Sea: satellite colour atlas. Cont Shelf Res 9:667-765

Holligan PM, Fernandez E, Aiken J, Balch WM, Boyd P, 
Burkill PH, Finch M, Groom SB, Malin G, Muller K, Purdie DA, Robinson C, Trees CC, Turner SM, Van der Wal P (1993a) A biogeochemical study of the coccolithophore Emiliania huxleyj in the North Atlantic. Global biogeochem Cycles 7(4):879-900

Holligan PM, Groom SB, Harbour DS (1993b) What controls the distribution of the coccolithophore, Emiliania huxleyi, in the North Sea? Fish Oceanogr 2(3/4):175-183

Holligan PM, Viollier M, Harbour DS, Camus P, ChampagnePhilippe M (1983) Satellite and ship studies of coccolithophore production along a continental shelf edge. Nature 304:339-342

Jacobson TR, Azam F (1984) Role of bacteria in copepod fecal pellet decomposition: colonization, growth rates and mineralization. Bull mar Sci 35:495-502

Kleijne A (1991) Holococcolithophorids from the Indian Ocean, Red Sea, Mediterranean Sea and North Atlantic Ocean. Mar Micropaleotol 17:1-76

Knappertsbusch M, Brummer GJA (in press) A sediment trap investigation of sinking coccolithophorids in the North Atlantic. Deep Sea Res

Krause $M$ (1981) Vertical distribution of faecal pellets during FLEX '76. Helgoländer Meeresunters 34:313-327

Kristiansen $S$, Thingstad $T F$, Van der Wal P, Farbrot $T$, Skjoldal EF (1994) An Emiliania huxleyi dominated subsurface bloom in Samnangerfjorden, western Norway. Importance of hydrography and nutrients. Sarsia 79(4) $357-368$

Lampitt R, Noji TT, Von Bodungen B (1990) What happens to zooplankton faecal pellets? Implications for material flux. Mar Biol 104:15-23

Lee C, Wakeham SG, Hedges GI (1988) The measurement of oceanic particles - are 'swimmers' a problem? Oceanography $1(2): 34-36$

Martens P (1978) Faecal pellets. Fiches Identif Zooplancton $162: 1-4$

McIntyre A, McIntyre R (1971) Coccolith concentrations and differential solution in oceanic sediments. In: Funneli BM, Reidel WR (eds) The micropalaeontology of oceans. Cambridge University Press, Cambridge, p 253-261

Nimer NA, Merrett MJ (1993) Calcification rate in Emiliania huxleyi Lohmann in response to light, nitrate and availability of inorganic carbon. New Phytol 123:763-677

Noji TT (1991) The influence of macrozooplankton on vertical particle flux. Sarsia 76:1-9

Noji TT, Estep KW, Macintyre F, Norrbin F (1991) Image analysis of faecal material grazed upon by three species of copepods: evidence for coprorhexy, coprophagy and coprochaly. J mar biol Ass UK 71:465-480

Otto L, Zimmerman JTF, Furnes GK, Mork M, Saetre R, Becker G (1990) Review of the physical oceanography of the North Sea. Neth J Sea Res 26(2-4):161-238

Paasche E (1964) A tracer study of the inorganic carbon uptake during coccolith formation and photosynthesis in

This article was submitted to the editor the coccolithophorid Coccolithus huxleyi. Physiol plant Suppl III 1-82

Paffenhöfer GA, Strickland JDH (1970) A note on the feedıng of Calanus helgolandicus on detritus. Mar Biol 5:97-99

Smetacek V (1980) Zooplankton standing stock, copepod faecal pellets and particulate detritus in Kiel Bight. Estuar coast mar Sci 2:477-490

Turner JT (1979) Microbial attachment to copepod fecal pellets and its possible ecological significance. Trans Am Microsc Soc 98:131-135

Van Bleijswijk JDL, Kempers ES, Van der Wal P, Westbroek P, Egge JK, Lukk T (1994a) Standing stocks of PIC, POC, PON and Emiliania huxleyi coccospheres and liths in sea water enclosures with different phosphate loadings. Sarsia 79(4):307-317

Van Bleijswijk JDL, Kempers ES, Veldhuis MJW, Westbroek $P(1994 \mathrm{~b})$ Cell and growth characteristics of types $A$ and B of Emiliania huxleyi (Prymnesiophyceae) as determined by flow cytometry and chemical analysis. I Phycol 30 $230-241$

Van Bleijswijk JDL, Van der Wal P, Kempers ES, Veldhuis MJW, Young JR, Muyzer G, De Vrind-De Jong E, Westbroek P (1991) Distribution of two types of Emiliania huxleyi (Prymnesiophyceae) in the northeast Atlantic region as determined by immunofluorescence and coccolith morphology. J Phycol 27:566-570

Van der Wal P, De Jong EW, Westbroek P, De Bruijn WC, Mulder-Stapel AA (1983) Polysaccharide localization, coccolith formation, and Golgi dynamics in the coccolithophorid Hymenomonas carterae. J Ultrastruct Res 85:139-158

Van der Wal P, Van Bleijswijk JDL, Egge JK (1994) Primary productivity and calcification rate in blooms of the coccolithophorid Emiliania huxleyi (Lohmann) Hay and Mohler developing in mesocosms. Sarsia 79(4):401-408

Veldhuis MJW, Kraay GW (1990) Vertical distribution and pigment composition of a picoplanktic prochlorophyte in the subtropical North Atlantic: a combined study of HPLCanalysis of pigments and flow cytometry. Mar Ecol Prog Ser 68:121-127

Voss M (1991) Content of copepod faecal pellets in relation to food supply in Kiel Bight and its effect on sedimentation rate. Mar Ecol Prog Ser 75:217-225

Westbroek P, Brown CW, Van Bleijswijk JDL, Brownlee C, Brummer G-J, Conte M, Egge JK, Fernandez E, Jordan R, Knappertsbusch $M$, Stefels J, Veldhuis MJW, Van der Wal P, Young JR (1993) A model system approach to biological climate forcing The example of Emiliania huxleyi. Global Planet Change 8:27-46

Young JR, Westbroek P (1991) Genotypic variation in the coccolithophorid Emiliania huxleyi. Mar Micropaleontol 18: 5-23

Zeitzschel BP, Diekmann P. Uhlmann L (1978) A new multisample sediment trap. Mar Biol 45:285-288

Manuscript first received: February 16, 1995

Revised version accepted: April 3,1995 